\title{
ANALISIS RISIKO TRANSAKSI PEMBAYARAN PERDAGANGAN INTERNASIONAL
}

\author{
Oleh \\ Rainer Prakuso Tobing: Pascasarjana UKI \\ Ir. Tarcisius Sunaryo, MA, Ph.D: Dosen UKI \\ Dr. Ir. Ketut Silvanita Mangani, MA: Dosen UKI \\ Email: Email:pps-mih@uki.ac.id: Dosen
}

\begin{abstract}
ABSTRAK
Perdagangan Internasional merupakan salah suatu sumber devisa bagi suatu negara, walapun banyak risiko yang bisa terjadi. Risiko yang ada mempunyai dinamika dan karakter tersendiri, yang harus selalu dicermati oleh Pelaku Ekspor - Impor, Per-bank-an, Pemerintah, dan pemangku kepentingan lainnya untuk selalu siap sedia menyiapkan langkah strategis mengantispasi risiko yang ada.

Perdagangan dunia memasuki pasar bebas, dimana disetiap negara para pelaku usaha mempunyai peluang untuk melakukan perdagangan. Pada era pasar bebas, banyak produk-produk yang bisa di ekspor maupun di impor untuk saling memenuhi kebutuhan pasar di masingmasing negara. Tetapi walaupun dikatakan pasar bebas, proses perdagangan tetap dalam kendali dan pengawasan negara, dan organisasi perdagangan dunia yang dibentuk untukitu.

Pada setiap tindakan perdagangan, pasti akan ada transaksi pembayaran, dimana pembayaran suatu produk adalah hal yang utama dari suatu transaksi. Metode pembayaran menjadi acuan utama dalam suatu proses transaksi yang dapat dirumuskan dalam suatu Surat Perjanjian legal. Pada setiap penentuan metode transaksi
\end{abstract}

pembayaran, pembuat kebijakan dalam hal ini pemerintah tidak bisa melakukan intervensi, karena kepakatan lebih menitik beratkan kepada keinginan para eksportir maupun importir.

Para pelaku usaha ekspor impor akan saling menjajaki dan melakukan negosiasi untuk menentukan dan menyepakati serta mengikatkan dalam suatu perjanjian yang salah satu isi perjanjian akan menjelaskan metode pembayaran.

Para eksportir maupun importir akan sepakat dengan metode pembayaran yang dirasakan memiliki Risiko paling kecil.

Permasalahan ketika Seseorang atau Perusahaan/ Badan Usaha ingin melakukan Perdagangan International antara lain ;

> Menentukan Metode Pembayaran, karena pembeli/ Buyer/ Importir danPenjual/ Seller / Eksportir tidak saling mengenal satu sama lain.

$>$ Hukum, Peraturan, Bahasa, dan kebiasaan yang tidak sama.

> Hambatan Tarif/ Pajak.

$>$ Politik dan Stabilitas di negara masing-masing.

$>$ Mata uang pembayaran.

D Handling dan Transportasi. 
Importir perlu waktu untuk melakukan pembayaran.

Sistem perbankan masing masing negara dalam proses pengiriman dana.

$>$ Penjual menginginkan pembayaran yang tepat waktu.

Karena terlalu banyaknya risiko yang harus diantisipasi oleh para pelaku ekspor impor, maka titik beratkan pembahasan dalam jurnal ini adalah risiko yang terjadi pada transaksi pembayaran.

Kata Kunci : Identifikasi dan mitigsi suatu potensi risiko.

\section{PENDAhuluaN}

\section{I.I. Latar Belakang}

Pada hakikatnya perdagangan antar negara telah dilakukan oleh manusia sejak ribuan tahun yang lalu, dimana pada saat itu orang akan pergi ke suatu negara dengan membawa dan menjual produk atau komoditi serta jasa yang dihasilkan, dan ketika kembali akan membeli produk yang dibutuhkan untuk negaranya. Di saat itu mata uang sebagai alat pembayaran dan cara/ metode pembayaran belum tercipta, sehingga transaksi pembayaran masih menggunakan cara "tukar barang" atau biasa disebut barter. Walaupun sangat tradisional, transaksi pembayaran dapat berjalan dengan baik.

Dalam sistem perdagangan internasional $\mathrm{Di}$ era global saat ini, pedagang tidak perlu lagi pergi ke negara tujuan dengan membawa barang/ produk yang akan dijual. Hal ini bisa terjadi karena peran perangkat digital dalam bidang komunikasi, transportasi, pembayaran yang sudah sangat maju, membuat transaksi perdagangan jadi mudah dilakukan. Prangkat digital menciptakan fleksibilitas, efisiensi serta mempercepat proses transaksi perdagangan antar negara maupun domestik, meskipun demikian kewaspadaan harus selalu ditingkatkan, sebab kemudahan yang yang diberikan melalui layanan digital membuka kesempatan bagi para pelaku kriminal bisnis untuk memanfaatkan celah kelamahan sistem digital tersebut dalam melakukan penipuan.

Seperti kita ketahui terjadi perdagangan akibat masingmasing Negara di dunia memiliki kelebihan dan kekurangan di bidang barang dan Jasa serta Sumber Daya, Tingkat Harga, Struktur Perekonomian, dan lainnya, sehingga dari hal tersebutlah maka terjadi transaksi Perdagangan untuk saling memenuhi atas kebutuhan masing-masing negara. Perdagangan antara Negara juga bertujuan untuk meningkatkan devisa Negara. Perdagangan antara negara lazimnya disebut Ekspor - Impor,yang merupakan transaksi sederhana yaitu menjual dan membeli suatu produk antara para pengusaha yang berbeda negara, waktu, budaya, maupun mata uang.

Dalam transaksi perdagangan antara negara Bank sentral suatu Negara memiliki peran sangat penting, untuk itu Bank sentral perlu memperkuat cadangan devisanya untuk menyediakan mata uang asing. Pada Perdagangan internasional umumnya digunakan mata uang Amerika, US dollar, Euro untuk ber transaksi.

Seperti kita ketahui perdagangan dunia saat ini memasuki phase Pasar Bebas atau Perdagangan Bebas. Pasar bebas dibangun bertujuan untuk menghilangkan hambatan- hambatan suatu produk masuk ke Negara tujuan, suatu produk dapat bebas masuk tanpa hambatan, tetapi walapun menganut pasar bebas, suatu Negara tetap perlu melakukan perlindungan terhadap produk dalam negerinya, dengan melakukan pembatasan bahkan pelarangan produk dari negara lain untuk masuk ke pasar negara tersebut.

Ekspor merupakan "transaksi perdagangan yang terjadi dengan mengeluarkan barang atau jasa dari suatu wilayah pabean yang memenuhi ketentuan yang berlaku di negara tersebut" ke negara lain yang menjadi tujuannya. Sedangkan Impor adalah transaksi perdagangan yang terjadi dengan memasukan barang atau jasa kedalam suatu wilayah pabean yang memenuhi ketentuan yang berlaku di negara tersebut". Setiap negara mempunyai kebijakan untuk mengatur apakah suatu produk atau jasa yang dihasilkan dapat di ekspor maupun di impor. Biasanya proses tersebut dilakukan melalui kebijakan Pemerintah melalui kebijakan pembatasan terhadap suatu barang dan jasa yang akan masuk maupun keluar dari negara tersebut. Kebijakan pembatasan ekspor dan impor umumnya dilakukan untuk melindungi produk yang diproduksi di negara tersebut, atau untuk tujuan agar para pengusaha negara lain melakukan investasi di negara tersebut dengan mendirikan pabrik, yang dapat meningkatkan pertumbuhan ekonomi negara tersebut.

Untuk mengamankan kebijakan pembatasan impor Pemerintah melakukan pengawasan terhadap produk import, atau dengan menetapkan batasan impor (kuota). Pengawasan biasa dilakukan pada wilayah pabean suatu Negara. Sedangkan Pabean merupakan instansi (jawatan, kantor) yang mengawasi, memungut, dan mengurus bea masuk / impor dan bea keluar ekspor, baik melalui darat, laut, maupun melalui udara. Kepabeanan sendiri berarti segala sesuatu yang berhubungan dengan pengawasan atas lalu lintas barang yang masuk atau keluar daerah pabean 
serta pemungutan bea masuk dan bea keluar.

Para pelaku kegiatan biasa disebut dengan eksportir, yang melakukan perdagangan antar negara dengan mengirimkan barang dan jasa bagi pembelinya di negara tujuan ekspor. Para eksportir dalam melaksanakan ekspor produk dilakukan dengan perjanjian kontrak pembelian dan penjualan yang sudah disepakati antara pengekspor dan pengimpor, seperti; jenis produk, jumlah produk, spesifikasi produk, harga, metode pembayaran, jadwal pengiriman, dan dokumen dokumen lainnya yang dibutuhkan oleh eksportir maupun importir.

Kontrak Perjanjian Penjualan dan Pembelian yang biasanya memuat syarat-syarat berdasarkan suatu periode waktu, penyerahan barang, spesifikasi produk yang dijelaskan dan dibahas secara rinci seperti; jumlah barang, harga barang, metode pembayaran, kemasan, hak dan kewajiban serta tanggung jawab yang diuraikan dalam kontrak pembelian secara detail, dan lainnya yang sesuai dengan kesepakatan. Banyak hal yang harus disepakati/ negosiasikan sebelum menandatanganinya.

Pembahas kontrak secara rinci dilakukan untuk menghindari atau memperkecil risiko yang ditimbulkan terutama terhadap risiko pembayaran.

Adapun beberapa risiko yang menjadi perhatian pada perusahaan ekportir dan importir seperti;

I. Risiko gagal bayar; kegagalan pembayaran oleh importir yang merugikaneksportir.

2. Risiko Pembiayaan; biaya yang dibayarkan importir untuk melakukanpembayaran.

3. Risiko Transaksi; importir atau eksportir bertujuan melakukan penipuan.

4. Risiko Mata Uang; naik turunnya nilai valuta asing.

5. Risiko Pembayaran Cara Kredit

6. Risiko Transportasi; biaya penggunaan asuransi

Gagalan bayar, umumnya sering terjadi pada eksportir, untuk menghindari risiko tersebut diperlukan identifikasi risiko dalam bertransaksi. Banyak risiko yang ditimbulkan terhadap para importir atau pun juga eksportir. Untuk itu dalam melakukan transaksi selain perjanjian yang sudah berlandaskan hukum, diperlukan naluri bisnis dalam menilai mitra kerja. Kekuatan naluri (insting) juga sangat berperan dalam menentukan suatu kesepakatan. Dampak dari berbagai risiko kegagalan penerimaan pembayaran pada perusahaan eksportir skala Kecil Menengah dapat mengakibatkan kebangkrutan. Bagi perusahaan skala Kecil umumnya dihadapkan pada suatu dilema, disatu sisi mereka membutuhkan pesanan dari importir, dan disisi lain mereka memiliki keterbatasan informasi sehingga sering mengalami risiko pembayaran.
Pada perdagangan internasional kesepakatan didasarkan pada aturan hukum yang berlaku di negara dimasingmasing tempat eksportir dan importir berdomisili.

Pada perusahaan yang berskala besar, umumnya sudah ada divisi legal yang menangani perjanjian kontrak, dan bahkan juga suatu perjanjian pembelian ditangani oleh suatu Firma Hukum (Law Firm), Notaris dan lainnya, sehingga apabila terjadi wanprestasi diantara para ekportir dan importir, dapat diselesaikan melalui suatu proses hukum. Sedangkan pada perusahaan berskala kecil menengah, surat perjanjian pembelian umumnya dibuat sederhana, lebih cenderung pada kepakatan kedua belah pihak yang berdasarkan kepercayaan.

Pada perusahaan ekspor impor berskala menengah kecil selalu terbentur kepada masalah harga dan pembiayaan, sehingga kesepakatan harga dan metode pembayaran menjadi menjadi hal utama dalam negosiasi.

Surat perjanjian yang dibuat secara legal dihadapan notaris merupakan salah satu bentuk mitigasi untuk mengingatkan kedua belah pihak, yakni eksportir dan importir bahwa apabila terjadi wanprestasi, dengan melanggar perjanjian yang telah disepakati bersama, maka kedua belah pihak dapat menyelesaikan masalah tersebut di Pengadilan.

Dari beberapa metode pembayaran yang dilakukan saat ini, metode pembayaran "payment against document dirasakan sangat ideal bagi kedua belah pihak, dimana saling berbagi Risiko. Eksportir dapat menerima pembayaran awal (down payment) sebagai jaminan pemesanan, dan importir dapat memaksimalkan dana yang ada pada aliran kasnya sambil menunggu saat pesanan produknya harus dibayar.

Dalam tahapan negosiasi, setelah kwalitas barang yang ditawarkan oleh pihak penjual/ eksportir dapat disetujui/ diterima oleh pihak pembeli/ importir, maka akan dibicarakan harga barang, bonus penjualan, dukungan promosi dan lainnya. Pada penawaran harga suatu barang, eksportir cenderung akan mengajukan penawaran harga secara FOB (Free on Board). Penawaran harga FOB dianggap lebih memudahkan eksportir karena tidak terlalu banyak urusan dengan pihak ketiga lainnya. Eksportir hanya akan mempersiapkan barang yang sesuai dengan spesifikasi yang diminta importir, dan dokumen dokumen yang dibutuhkan. Eksportir bertanggung jawab untuk mengurus dan menerbitkan seluruh dokumen ekspor yang diperlukan, baik untuk pabean di negara pengirim maupun untuk pabean di negara penerima.

Ada 3 model penawaran harga produk yang biasa ditawarkan ; 
I. Harga FOB (Free on Board); yaitu harga barang yang ditawarkan dan disepakati antara eksportir dan importir hanya sampai di pelabuhan pengiriman, batas pabean. Importir akan bekerjasama dengan perusahaan pelayaran maupun penerbangan untuk pengiriman barang tersebut. Biaya transportasi dan asuransi pengiriman ke negara tujuan menjadi tanggung jawab importir.

2. Harga CnF (Cost and Freight), yaitu harga yang ditawarkan dan disepakati antara importir dan eksportir termasuk biaya pengiriman tanpa membayar asuransi. Asuransi akan dibayar oleh importir secara terpisah. Eksportir bertanggung jawab untuk mendapatkan perusahaan pelayaran maupun penerbangan untuk mengirimkan barang yang dibeli oleh importir. Dokumen ekspor dan pengiriman akan diurus dan diterbikan oleh pihak eksportir.

3. Harga CIF (Cost Insurance Freight), yaitu harga yang ditawarkan dan disepakati antara eksportir dan importir sudah termasuk biaya pengiriman dan asuransi pengiriman. Eksportir bertanggung jawab untuk mendapatkan perusahaan pelayaran maupun penerbangan, menentukan jadwal pengiriman, dan membayarkan asuransi, menyediakan seluruh dokumen ekspor yang diperlukan. Importir tinggal menunggu di negaranya dan mengurus pengeluaran barang di pabean negaranya.

Setelah harga disepakati, eksportir akan menerbitkan Proforma Invoice yang sesuai dengan standar formulir di perusahaan eksportir tersebut. Proforma Invoice yang diterbitkan oleh eksportir dikirimkan kepada importir. Importir akan menandatangani proforma invoice untuk menyatakan persetujuannya. Pada proforma invoice tertera secara jelas dan lengkap; spesifikasi barang/ produk, jumlah barang yang sesuai dengan masing-masing spesifikasi, harga barang yang sesuai dengan masing-masing spesifikasi, jadwal pengiriman oleh eksportir secara FOB atau CIF, metode pembayaran, dan kondisi kondisi lain sesuai kesepakatan awal. Proforma Invoice dapat juga dikatakan seperti Surat Pesanan yang diterbitkan oleh importir pada saat akan memesan barang/ produk.

Ada beberapa metode pembayaran yang biasanya digunakan oleh para eksportir dan importir. Penggunaan kedua metode tersebut sangat tergantung dari tingkat kepercayaan dan keyakinan masing-masing pihak. Pada perusahaan skala kecil menengah, kesepakatan metode pembayaran umumnya menggunakan beberapa pendekatan. Ada 2 (dua) jenis pembayaran yang digunakan oleh para eksportir dan importir yaitu ;

I. Non Letter of Credit (Non L/C)

2. Letter of Credit (L/C).
Non L/C dan L/C masih terbagi lagi pada beberapa metode pembayaran.

Beberapa Metode pembayaran yang bisa digunakan dalam proses eskpor impor adalah sebagai berikut :

Diagram I:

Metode Pembayaran Transaksi Perdagangan Intenasional

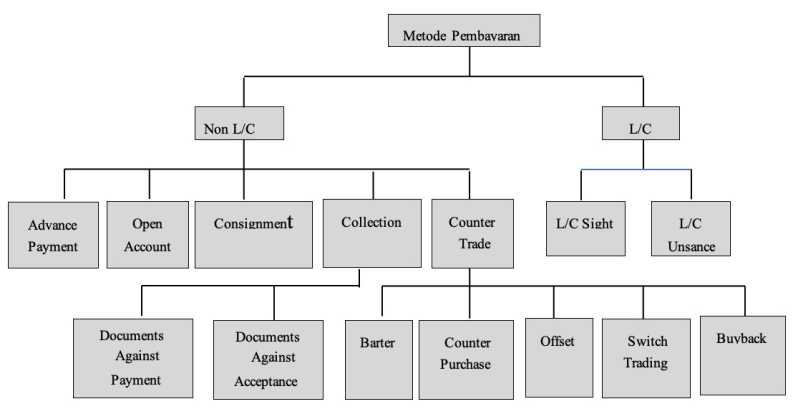

Sumber : Direktorat Jenderal Pengembangan Ekspor Nasional - Kementerian Perdagangan Republik Indonesia

Dibawah ini beberapa metode pembayaran yang umumnya disepakati antaraeksportir dan importir ;

I. Advance Payment, (Pembayaran dimuka s e b e I u m pesanan barang dikirimkan kepada importir)

2. Open Account/ Cash on Delivery, (Pembayaran pada saat pesanan barangditerima oleh si pemesan/ importir)

3. Collection; Payment Against Document, (Pembayaran/ Pelunasan dilakukan setelah barang dikirimkan dengan jaminan dokumen ekspor)

4. Consignment (Titip jual; importir membayar kepada eksportir setelahbarang terjual)

5. Letter of Credit (L/C),

Kelima metode pembayaran diatas masing-masing memiliki risiko bagi para eksportir maupun importir, oleh karena itu kesepakatan metode pembayaran sangat memegang peranan penting dalam suatu negosiasi.

Adapun tujuan penelitian ini untuk:

I. Memetakan proses pembayaran dan mengidentifikasi peta kejadian yang tidak diinginkan (KTD).

2. Menentukan besarnya risiko pada setiap metode pembayaran..

3. Memitigasi atau mengeliminir risiko yang ada pada setiap elemen metode pembayaran.

\section{LANDASAN TEORI}

\section{Tinjauan Pustaka}

Tinjauan pustaka yang digunakan pada penelitian ini 
adalah Undang undang Republik Indonesia, Peraturan Pemerintah RI, buku buku tentang ekspor impor, serta jurnal jurnal yang sesuai dengan tujuan penelitian.

I. Undang-Undang Republik Indonesia Nomor 7 Tahun 2014 Tentang Perdagangan.

2. Undang-Undang Republik Indonesia Nomor 20 Tahun 2008 Tentang Usaha Mikro, Kecil Menengah.

3. Peraturan Pemerintah Repubuk Indonesia Nomor 29 Tahun 2017 Tentang Cara Pembayaran Barang Cara Penyerahan Barang Dalam Kegiatan EksporDan Impor.

4. Dan lainya.

Ekspor bertujuan untuk menaikkan devisa penerimaan Negara, dan import lebih kepada pengeluaran devisa negara. Perdagangan internasional membutuhkan sumber pembiayaan yang sangat penting yaitu cadangan devisa. Cadangan devisa merupakan posisi bersih aktiva luar negeri pemerintah dan bank-bank devisa, yang harus dipelihara untuk keperluan transaksi internasional (Rachbini dan Swidi, 2000: I 13).

Kardoyo, dan Ahmad Nurkhin, mengatakan ; Devisa merupakan aset atau kewajiban finansial yang digunakan dalam transaksi internasional. Perpindahan aset dan kewajiban finansial antara penduduk di satu negara dengan penduduk di negara lain akan menimbulkan lalu lintas devisa.

Keunggulan komparatif dari kegiatan ekonomi suatu Negara menunjukkankeunggulan dalam hal potensi sumber daya alam, kemampuan teknologi dan manajerial dalam pengelolaan kegiatan ekonomi yang bersangkutan (Saptana 2010; Sapta et al.20 I3; Fahmi et al. 2015; Turnip et al. 2016).

Kardoyo, dan Ahmad Nurkhin,. M.Si mengatakan ; Terhadap barang tertentu, pemerintah dapat mengeluarkan kebijakan larangan ekspor atau impor. Kebijakan larangan impor umumnya bertujuan untuk melindungi produsen di dalam negeri. Larangan impor juga diberlakukan untuk barang- barang yang dapat merugikan masyarakat, misalnya minuman beralkohol dan limbah berbahaya. Sedangkan larangan ekspor ditujukan untuk melindungikonsumen di dalam negeri. Terutama jika kebutuhan barang di dalam negeri belum terpenuhi seperti; Beras, Gula, Rempah, dan lainnya yang menjadi komoditi pokok masyarakat.

\section{A. Tinjauan Umum Perusahaan}

Suatu Perusahaan atau Badan Usaha didirikan berdasarkan Akte Pendirian yang diterbitkan oleh Notaris Pejabat Negara, sertaAkte Perusahaan yang diterbitkan oleh Notaris wajib mendapatkan pengesahan dari Kementerian Hukum dan Hak Asasi Manusia c/q Direktorat Jenderal
Administrasi Hukum Umum.

Sebelum memulai usaha, setiap Badan Hukum dan wajib memiliki beberapa perijinan yang dipersyaratkan untuk menjalankan usahanya. Minimal perijinan yang diperlukan antara lain ;

I. Memiliki NPWP (Nomor Pokok Wajib Pajak).

2. Keterangan Domisili yang diterbitkan oleh pemerintah daerah setempat, dimana lokasi kantor dan/atau pabrik perusahaan tersebut melakukan aktifitas usaha.

3. Memperoleh NIB (Nomor Induk Berusaha) yang menandakan bahwa perusahaan tersebut sudah mendapatkan ijin usaha perdagangan.

4. Perijinan Industri

5. Perijinan lainnya yang sesuai dengan karakter usahanya.

\section{B. Tinjauan Umum Dokumen Ekspor}

Setiap kegiatan ekspor harus dilengkapi dengan dokumen yang sah. Pengeluaran barang oleh importir di negara penerima, harus menyertakan dokumen ekspor dalam bentuk asli, bukan foto copy. Ketidak lengkapan dokumen pengiriman bisa menghambat pengeluaran barang dari wilayah pabean pengiriman maupun pemasukan di wilayah pabean memasukan barang. Dokumen yang standar dan umumunya berlaku ;

I. Invoice ; adalah kwitansi untuk menyatakan barang yang dibeli sudah dibayar lunas secara administrasi.

2. Packing List ; adalah daftar barang yang dikirimkan diuraikan secara rinci nama barang, jumlah, berat dan lainnya yang sesuai dengan spesifikasi barang.

3. Certificate of Origin (COO) ; adalah sertifikat yang menyatakan asal negarabarang yang dikirimkan, negara asal pengiriman.

4. Bill of Leading ; adalah dokumen pengiriman barang yang diterbitkan oleh pelayaran yang mengirimkan barang.

5. Pemberitahuan Ekspor Barang (PEB) ; adalah dokumen yang diterbitkan oleh pihak pabean

6. Dokumen lainnya seperti ; sertifikat karantina untuk produk produk pertanian, sertifikat asal kayu untuk produk produk furniture, dan sertifikat laiannya sesuai persayaratan yang ditentukan terhadap barang yang dikirimkan.

\section{Transfer Risiko}

Pada perdagangan luar negeri, ada risiko yang dapat ditransfer secara internal kepada importir maupun kepada eksportir. Transfer risiko secara internal dapat merupakan 
pengenaan biaya penalti/ denda atas kesalahan yang dilakukan oleh salah satu.

Selain transfer risiko secara internal, dapat juga dilakukan transfer risiko kepada pihak ketiga seperti; mengasuransikan barang yang dikirim dengan kapal laut maupun udara, menyertakan suveyor independen untuk melakukan pemeriksaan barang; spesifikasi, kuantitas, dokumen, dan lainnya, sebelum barang diberangkatkan.

\section{Penanganan Wanprestasi}

Seringkali terjadi wanprestasi dalam perdagangan internasional, bentuk pelanggaran umumnya sekitar masalah pembayaran, barang dikirimkan tidak sesuai dengan pesanan. Untuk penanganan hal tersebut biasanya menggunakan pendekatan secara musyawarah dan mufakat, tetapi apabila jalan damai yang ditempuh mengalami kebuntuan, maka permasalahan tersebut dapat dibawa ke Arbitrase International.

\section{E. Proses Pembangunan Reputasi}

Reputasi para eksportir dan importir di pertaruhkan pada suatu perdagangan, baik yang domestik maupun internasional. Kesalahan yang mengakibatkan pihak lain, akan menjatuhkan kredibilitas yang dapat mengakibatkan hilangnya kepercayaan yang diberikan. Ini tidak sebatas kepada kedua pihak importir dan ekportir, tapi juga dapat diketahui dan didengar oleh pelaku bisnis lainnya.

\section{F. Tinjauan Metode Pembayaran}

Dibawah ini ada 5 (Lima) Metode Pembayaran yang selama ini banyak digunakan dalam suatu transaksi pembayaran dikalangan pelaku usaha Ekspor - Impor, yang terbagi atas pembayaran dengan metode Non Letter of Credit (Non LC) dan Metode Letter of Credit (L/C).;

\section{a. Metode Pembayaran Non L/C sebagai berikut ;}

\section{Advance Payment / Cash Before Delivery/ Pembayaran Dimuka}

Metode pembayaran ini biasa disebut "dibayar dimuka". Pembeli melakukan pembayaran pelunasan terlebih dahulu melalui transfer, kartu kredit, atau bahkan pembayaran kontan, sebelum barang dikirimkan, Setelah eksportir yakin telah menerima pembayaran, barulah produk yang dibeli di proses pengadaannya dan dikirimkan. Metode pembayaran ini paling sederhana dan paling kecil risikonya bagi eksportir, tetapi tidak disenangi oleh importir. Karena importir harus menanamkan kepercayaan yang tinggi terhadap eksportir. Umumnya advance payment dilakukan oleh importir yang mempunyai alur kas yang kuat dan benar-benar telah mengenal eksportir, dan melihat fasilitas produksi/ pabrik milik ekportir. Di beberapa Negara yang mengenakan biaya tinggi terhadap pembukaan L/C, terbatasnya valuta asing pada bank sentral, para importirnya lebih memilih advance payment sebagai metode pembayaran. Bagi pengusaha yang berskala Kecil dan Menengah, metode pembayaran ini sangat disenangi.

Faktor yang mendorong dilakukannya pembayaran dengan sistem tunai ini, antara lain:

I. Kepercayaan dari importir kepada eksportir

2. Keyakinan yang dimiliki importir terhadap negara eksportir bahwa negara eksportir tidak akan melarang ekspor

3. Pemerintah importir memberikan izin untuk melakukan pembayaran diawal kepada importir

4. Importir mempunyai likuiditas yang cukup

\section{Open Account / Cash on Delivery/ Pemba- yaran Kemudian}

Metode pembayaran dalam cash on delivery / open account/ pembayaran kemudian adalah kebalikan dari metode pembayaran advance payment. Metodepembayaran ini lebih be-risiko bagi Eksportir/ penjual karena Eksportir sudah harus lebih dahulu mempersiapkan, memproduksi pesanan dan mengirimkan sebelum menerima pembayaran tanda jadi (down payment) apapun. Importir/ pembeli wajib melakukan pembayaran mentransfer dananya dalam waktu yang telah disepakati atau sesaat setelah importir mengirimkan bukti telah melakukan pengiriman barang melalui agen pengiriman atau pada saat pesanan telah diterima dengan baik oleh Importir. Bagi eksportir/ penjual, motode ini sangat berisiko. Metode ini umumnya dilakukan oleh pebisnis yang sudah saling kenal satu sama lain, dan saling memiliki kepercayaan yang tinggi antara eksporti dan importir. Metode pembayaran ini tidak bisa terjadi bagi eksportir dan importir yang baru saling kenal. Biaya bank untuk metode ini relatif kecil/ murah, hampir sama dengan metode advance payment

Cara pembayaran export dan import dengan sistem Rekening Terbuka atau yang sering disebut Pembayaran Kemudian (Open Account) dapat dilakukan, apabila :

I. Ada kepercayaan penuh antara pihak eksportir dan 
importir

2. Barang-barang dan dokumen akan dikirim langsung kepada pembeli

3. Eksportir mempunyai dana lebih

4. Pihak eksportir yakin tidak ada peraturan di negara importir yang melarang transfer pembayaran

Risiko yang bisa saja terjadi dalam sistem pembayaran Open Account adalah :

I. Eksportir tidak mendapat perlindungan apakah importir akan melakukan pembayaran

2. Apabila importir tidak membayar, eksportir akan mengalami kesulitan ketika membuktikannya saat di pengadilan karena tidak adanya bukti

3. Penyelesaian perselisihan dalam hal ini akan mengakibatkan pihak eksportir harus mengeluarkan biaya lebih

\section{Collection Payment - Against Document}

Metode pembayaran Against Document lebih banyak dilakukan daripada Metode Cash Before Delivery atau Metode Cash On Delivery. Metode ini dirasakan memiliki risiko yang setara diantara importir dan eksportir. Metode ini adalah dimana importir/pembeli melakukan pembayaran dengan termin. Misalnya pembayaran awal (down payment) dibayarkan oleh importir sebesar $30 \%$ dari nilai pesanan (proforma inivoice) sangat tergantung dari hasil negosiasi. Setelah pesanan dikirimkan (shipment) oleh eksportir/penjual, bersamaan dengan perjalanan kapal menuju pelabuhan importir, ekportir akan mengirimkan copy dokumen ekspor melalui facsimile ataupun email, copydokumen yang diterima oleh importir akan diperiksa, apabila copy dokumen ekspor sudah sesuai dengan yang dipersyaratkan dalam perjanjian jual beli, maka importir melakukan pembayaran sisanya yang $70 \%$.Setelah menerima pembayaran pelunasan dari importir, maka eksportir akan mengirimkan dokumen ekspor asli, kepada importir. Dokumen asli ekspor menjadi syarat untuk mengeluarkan produk yang dibeli di pabean negara importir.

\section{Consignment / Titip Jual}

Metode consignment atau yang biasa disebut tiitip jual adalah suatu metode yang sudah jarang dilakukan. Metode ini adalah dimana eksportir mengirimkan terlebih dahulu barang/ produknya kepada importir untuk dijual, tanpa pembayaran terlebih dahulu dari dari importir. Importir akan membayar kepada eksportir setelah barang/ produk terjual, dan sisa barang yang tidak terjual dikirim kembali kepada eksportir. Sangat mengandung risiko yang tinggi bagi eksportir, sehingga diperlukan tingkat kehati-hatian yang tinggi dan akurat.

Metode ini bisa dilakukan apabila eksportir dan importir sudah saling mengenal, saling percaya, tidak ada keraguan dalam bertransaksi, atau ekportir dan importir adalah menjadi satu bagian yang sama dalam suatu badan usaha.

\section{Letter of Credit (L/C)}

Letter Credit atau biasa disingkat L/C, saat ini dinilai cara pembayaran dalam perdagangan internasional yang paling aman. L/C dapat dikatakan sebagai mitigasi dari seluruuh metode pembayaran. Risiko pembayaran dengan menggunakan L/C relatif lebih sedikit dan kecil.

Mekanisme kerja pembayaran dengan menggunakan L/C akan melibatkan sebuah bank, bank yang menerbitkan L/C akan memberikan jaminan bahwa importir akan melakukan pembayaran sesuai dengan persyaratan dan kesepakatan yang disetujui antara eksportir dan importir yang tertulis pada klausul Letter of Credit. Sebelum menerbitkan L/C untuk importir, pihak bank penerbit (issuing bank) akan melakukan analisis risiko, yang mirip dengan analisis saat menyalurkan kredit, kondite dan likuiditas importir menjadi pertimbangan. Kredibilitas bank penerbit sangat mempengaruhi, sehingga tidak semua bank dapat menerbitkan L/C yang bisa dipercaya. Nilai yang wajib dibayarkan oleh bank penerbit L/C harus disetorkan oleh pihak importir kepada bank. Bagi nasabah bank yang sudah lama menjalin hubungan dengan pihak Bank, kredibilitas dan kondite usaha sudah dinilai baik oleh pihak Bank, umumnya bisa mendapatkan fasilitas pembiayaan terhadap penerbitan L/C dari pihak Bank. Pihak eksportir umumnya akan mempersyaratkan pihak importir dengan memberikan beberapa nama bank yang dianggap kredibel untuk menerbitkan L/C berdasarkan rekomendasi dari bank penerima (mewakili eksportir). Bank penerbit L/C sudah mempunyai hubungan kerja koresponden dengan bank penerima, sebagai jaminan bahwa bank tersebut tidak akan bermasalah pada saat L/C jatuh tempo pembayaran Ini untuk lebih meyakinkan agar tidak terjadi gagal bayar,. Umumnya pihak eksportir lebih menginginkan L/C diterbitkan oleh bank yang sudah besar, bank pemerintah, dan mempunyai kredibiltas yang tinggi. Biaya penerbitan L/C lebih mahal dibandingkan dengan metode pembayaran transfer. Metode ini sangat aman bagi eksportir, dan juga Eksportir bisa mendapatkan fasiltitas pembiayaan dari 
pihak bank penerima dengan meng-agun-kan L/C. Bagi Importir metode ini mengandung Risiko, apabila pesanan gagal dikirimkan oleh produsen, maka biaya proses dan penerbitan L/C sangat mahal, yang menjadi tanggungan Eksportir.

Ada beberapa type Letter of Credit ;

\section{Revocable dan Irevocable L/C}

Revocable L/C adalah L/C yang sewaktu-waktu dapat dibatalkan atau diubah secara sepihak oleh pembeli/ importir atau issuing bank tanpa persetujuan atau pemberitahuan kepada penjual/eksportir atas permintaan Applicant. L/C ini banyak digunakan dengan anak/cabang perusahaannya atau antara perusahaan yang sudah saling mempercayai.

Irrevocable L/C adalah L/C yang tidak dapat diubah atau dibatalkan tanpa persetujuan kedua belah pihak dan issuing bank menjamin akan membayarnya asal saja si eksportir menyerahkan dokumen yang cocok dengan L/C dan diserahkan tidak melampaui batas waktu yang ditetapkan dalam L/C.

\section{Banker's L/C}

Banker's L/C adalah L/C yang dibuka oleh suatu bank atas permintaan importir dan bank tersebut bertanggung jawab atas pembayaran L/C apabila semua syarat-syarat dalam L/C dipenuhi. Dengan kata lain Bank mengambil alih seluruh kewajiban membayar sehingga terjadi substitusi dari kemampuan melunasi olah Opening Bank.

\section{Confirmed L/C}

Sifat khusus suatu Banker's L/C adalah credit standing bank dan importir dalam L/C tersebut. Hal ini bisa di ajukan olah eksportir jika Bank pembuka tidak mempunyai reputasi Internasional dan situasi politik ekonomi yang mengharuskan demikian, sehingga eksportir memandang perlu untuk meminta jaminan kepada advising bank/ Negotiating bank. Dan ekspotir mengajukan agar dibukakan suatu Confirmed L/C atau lengkapnya disebut Confirming irrevocable L/C yaitu L/C yang tidak dapat dibatalkan sepihak dan dijamin sepenuhnya oleh confirming bank.

\section{Commercial L/C}

Commmercial letter of credit adalah L/C yang dibuka oleh bank atas permintaan nasabahnya, tetapi dikirimkan langsung kepada Beneficiary tidak melaluio Advising Bank. Commercial L/C ini dimaksudkan agar eksportir bisa dengan cepat menerima L/C dan bisa menegosiasikan weselnya pada beberapa bank (tidak terbatas pada satu bank) dengan jalan menyerahkan dokumen dan Commercial L/C yang asli. Dan Bank yang membayar wesel akan mencatat pada commercial L/C asli jumlah pembayaran yang telah dilakukan.

Secara khusus Letter of Credit dapat dibedakan sebagai berikut :

a. Red Clause L/C

Red Clause L/C adalah L/C dimana issuing banknya memberikan kuasa kepada paying bank unutuk membayar uang muka kepada Beneficiary sebagian dari jumlah L/C sebelum beneficiary menyerahkan dokumen. Artinya L/C ini memiliki klausul dengan tinta merah yang menyatakan bahwa advising/confirming bank dapat melakukan pembayaran di muka kepada eksportir/penjual/beneficiary sebelum penyerahan dokumen pengiriman barang dilakukan. L/C semacam ini sering digunakan untuk menyediakan dana/kredit bagi eksportir sebelum barang dikapalkan. Dan beneficiary harus membuat pernyataan bahwa dokumen-dokumen yang diminta dalam L/C akan diserahkan pada waktunya.

b. Green-Ink L/C

L/C ini hampir sama dengan red-clause L/C yang memberikan pembayaran di muka dengan syarat eksportir harus menyerahkan kepada advising/ negotiating bank yang ditunjuk suatu bukti atau tanda terima penyimpanan barang dari warehouse sampai beneficiary siap untuk mengapalkan barang tersebut.

c. Revolving L/C

Pada L/C jenis ini, nilainya dapat diperbaharui sesuai dengan nilai yang tercantum didalamnya berdasarkan syarat-syarat yang ditetapkan misalnya tentang nilai maksimum, kumulatif atau non-kumulatif dan dapat dipakai berulang-ulang. Dalam kontrak jual beli ditetapkan seluruh total nominal dan pengiriman barang serta L/C disesuaikan secara bertahap.

d. Transferable L/C

Pada L/C ini, beneficiary/ eksportir dapat dipindah tangankan berdasarkan instruksi khusus dari applicant atau importir/pembeli dan syarat-syarat yang ditetapkan dalam L/C tersebut artinya beneficiary diberi wewenang untuk menyerahkan pelaksanaan ekspornya kepada pihak ketiga, baik sebagian maupun seluruhnya. 
e. Back to back L/C

Suatu kemungkinan lain dari Transferable L/C adalah Back to Back L/C, jika beneficiary meminta kepada Applicant agar L/C yang dibukanya bersifat transferable. Jadi Applicant mengetahui bahwa beneficiary itu bukanlah eksportir yang sebenarnya dari barang yang dipesan. Eksportir yang sebenarnya adalah pihak ketiga (namanya biasa dirahasiakan, bisa menjual dengan harga lebih murah). Setelah Beneficiary menerima L/C, Si beneficiary meminta kepada advising bank supaya membuka L/C baru kepada pihak ketiga yang merupakan eksportir sebenarnya. Dan L/C kedua ini mengandung syarat- syarat yang sama seperti $L / C$ yang pertama.

f. Stand by L/C

Jenis L/C ini merupakan L/C yang diberikan issuing bank atas permintaan applicant (kontraktor, debitor) sebagai jaminan khusus yang menyangkut fungsi financial kepada pihak beneficiary dan dipakai standby oleh beneficiary atau bank atas nama nasabahnya. Beneficiary credit ini dapat bertindak apabila si applicant gagal untuk memenuhi atau melaksanakan kontraknya, atau membayar kewajiban hutangnya (wanprestasi/ cedera janji terhadap beneficiary). Maka pihak bank akan membayar sejumlah uang yang telah ditentukan kepada beneficiary.

\section{g. Restricted L/C}

Jenis L/C ini merupakan L/C yang pembayarannya dibatasi (restricted) hanya kepada /melalui bank di negara beneficiary yang namanya tercantum pada L/C tersebut

h. Sight L/C

Sight letter of credit adalah L/C yang cara pembayarannya oleh negotiating bank dilakukan pada saat wesel-wesel ditunjukan oleh beneficiary disertai dokumen-dokumen lain yang disyaratkan dalam L/C. Pada umumnya Sight L/C ditujukan secara khusus kepada bank-bank koresponden diluar negeri di mana bank pembuka L/C mempunyai rekening dan bank penerima L/C sekaligus juga bertindak sebagai paying bank.

i. Usance L/C

Usance L/C ini pelaksanaan pembayarannya dilakukan pada saat jatuh tempo wesel berjangka (usance draft) dengan kata lain merupakan pemberian kredit oleh eksportir kepada importir untuk jangka waktu antara 90 hingga 180 hari dengan menerbitkan time/draft/ wesel. Pemberian fasilitas kredit ekspor dimaksudkan untuk mendorong pemasaran produk ke pasar ekspor. Bila eksportir memerlukan dana dapat mencairkan draft/weselnya dengan mendiskonto pada bank.

j. Merchant L/C

Merchant L/C dibuka oleh importir (bukan oleh bank), bisa dikirim kepada beneficiary langsung lewat perantaraan banknya yang untuk menjaminpembayaran draft pada saat jatuh tempo, tetapi bank tidak bertanggungjawab atas pembayaran $\mathrm{L} / \mathrm{C}$ tersebut.

Berikut ini adalah tiga kontrak terpisah yang dikaitkan dengan L/C, antara lain;

I. Kontrak jual beli (sales contract) antara penjual dan pembeli (eksportir danimportir)

2. Instrumen L/C yang merupakan kontrak antara eksportir (beneficiary) dan bank pembuka L/C (issuing bank)

3. L/C atau "perjanjian jaminan" yang merupakan kontrak antara importir (applicant) dan bank pembuka L/C (issuing bank)

\section{METODE PENELITIAN}

Dalam melakukan penelitian, peneliti menggunakan metode Expet Judgment, yaitu sesuatu kejadian yang berdasarkan pengalaman. Hal hal yang menjadi pengalaman tersebut ter-identifikasi melalui ; Forum Group Discussion (FGD) tentang Peluang Ekspor dan Tantangannya, diadakan Kamar Dagang dan Industri bersama para pengusaha ekspor impor. Indonesia - Russia Business Forum, yang diadakan oleh Kedutaan Besar Republik Indonesia di Moscow, Seminar Penguatan Ekspor Guna Peningkatan Devisa, yang diadakan oleh Kamar Dagang dan Industri, serta penelitan ke PT. Anugerah Pertiwi Mandiri, suatu perusahan perdagangan yang bergerak dibidang ekspor impor.

Selain dari pengalaman peneliti, data Kejadian Tidak Diinginkan (KTD) diperoleh dan dikumpulkan oleh peneliti dari rekan rekan para pengusaha pelaku ekspor impor.

\section{A. Tempat Dan Waktu}

Penelitian dilakukan di PT.Anugerah Pertiwi Mandiri dan mengikuti beberapa Seminar dan Forum Group Discussion (FGD) yang dilakukan dikalangan para pengusaha/ perusahaan yang bergerak dibidang ekspor impor yang ada 
di wilayah Jakarta dan sekitarnya. Perusahaan yang menjadi fokus utama dalam penelitian ini adalah perusahaan yang berskala Kecil dan Menengah yang sesuai dengan ketentuan pemerintah.

\section{B. Pelaksanaan Penelitian}

- Penelitian akan difokuskan pada suatu kejadian yang tidak diingankan dalam proses transaksi pembayaran.

- Sebelum melakukan penelitian, peneliti mengumpulkan data dan informasi dari hasil suatu Forum Group Discussin (FGD), Seminar yang diadakan oleh Kementerian Perdagangan, Kamar Dagang dan Industri, serta Asosiasi yang bergerak dibidang ekspor impor.

- Peneliti juga melakukan penelitian di perusahaan PT. Anugerah Pertiwi Mandiri yang berusaha di bidang ekspor-impor.

\section{C.Identifikasi Risiko}

Pada penelitian ini, peneliti akan mengidentifikasi risiko risiko yang ada dari suatu Kejadian Tidak Diinginkan pada setiap metode pembayaran yang selama ini digunakan untuk transaksi pembayaran oleh para pelaku ekspor-impor.

\section{D.Mengukur Risiko}

Hasil indetifikasi risiko, akan diukur sesuai besaran nilai peluang dan dampak dari suatu risiko yang akan dihadapi oleh pelaku ekspor-impor. Peneliti menyusun skoring daripada Kejadian Tidak Diinginkan dari setiap metode pembayaran sesuai dengan tingkat Risiko yang ada pada metode tersebut, skoring risiko akan ditampilkan dari risiko terendah dampai tertinggi, sehingga dapat menjadi pertimbangan dan pilihan bagi pengusaha skala kecil menengah yang akan melakukan perdagangan internasional.

Penelitian dititik baratkan pada Expert Judgement, yaitu berdasarkan kejadian dan pengalaman yang dialami oleh para pengusaha ekspor-impor. Selain dari pengalaman tersebut, Peneliti juga meneliti di salah satu perusahaan yang bergerak dibidang ekspor-impor untuk memperbandingkan kejadian dari tempat lain.

Peneliti mendapatkan dan mengumpulkan informasi dan data dari para perusahaan ekspor-impor di setiap metode pembayaran yang sering mereka sepakati dalam transaksi perdagangan ekspor impor.

\section{E. Mengukur peluang dan dampak}

Peluang : Berdasarkan pada data Historis Dampak : Berdasarkan estimasi

\section{F. Rumus dan Skala untuk mengukur risiko}

Mengukur risiko hasil dari dampak (impact) dikali peluang (probability)dari suatu kejadian yang tidak diinginkn. Pendekatan untuk mengukur besarann risiko dengan dengan menggunakan rumus dan risk mapping dibawah ini:

$$
L=P X D
$$

Keterangan :

L : Loss/RisikoP:Peluang D : Dampak

Sumber:T. Sunaryo, 20I5, Risiko Operasional

Tabel 3.I.: Pengukuran Kelompok Risiko

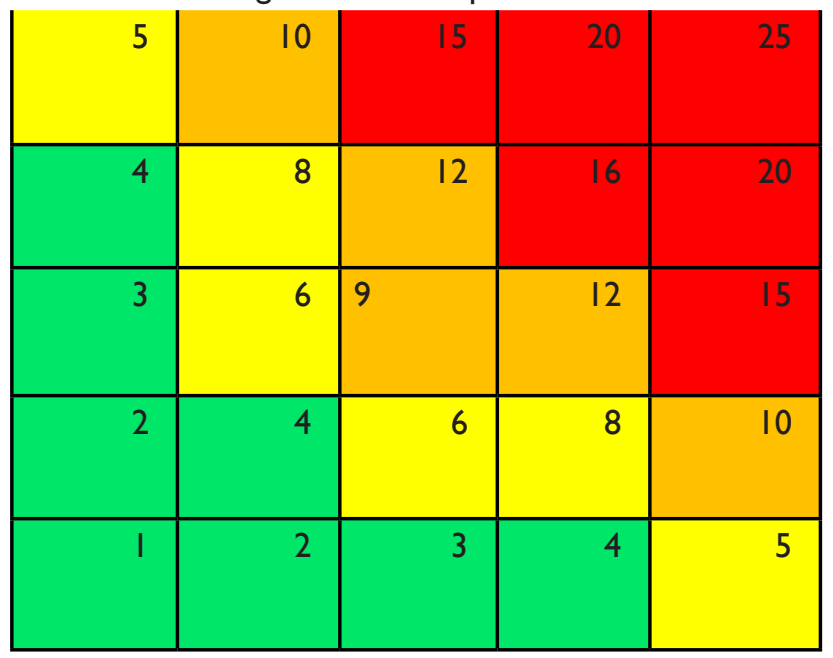

Tabel 3.2. : Skala Ukuran Kejadian Tidak Diinginkan

\begin{tabular}{|c|c|c|}
\hline Peluang & Dampak & Skala \\
\hline Jarang Terjadi & Kecil & $\mathrm{I}-2$ \\
\hline Sering Terjadi & Besar & $3-5$ \\
\hline
\end{tabular}


Tabel 3.3. : Skala Nilai Pengukuran Risiko

\begin{tabular}{|c|c|c|}
\hline $\begin{array}{c}\text { Peluang x } \\
\text { Dampak }\end{array}$ & Kategori & Warna \\
\hline $1-4$ & Sangat Rendah & \\
\hline $5-8$ & Rendah & \\
\hline $9-14$ & Sedang & \\
\hline $16-20$ & Tinggi & \\
\hline $21-25$ & $\begin{array}{c}\text { Sangat Tinggi/ Ek- } \\
\text { strim }\end{array}$ & \\
\hline
\end{tabular}

\section{PENELITIAN DAN PEMBAHASAN}

Identifikasi masalah dalam metode pembayaran ini diperoleh dari hasil hasil ; Forum Group Discussion (FGD), Seminar dan Forum Bisnis, serta pengalaman perusahaan dalam menjalankan usaha dibidang Ekspor - Impor. Peneliti melakukan penelitian di perusahaan yang sudah melakukan perdagangan internasional yang cukup panjang. Penelitian yang dilakukan berdasarkan sesuatu kejadian yang berdasarkan pengalaman.

PT.Anugerah Pertiwi Mandiri (APM), suatu perusahaan yang bergerak dibidang perdagangan / trading ekspor - impor untuk barang barang umum seperti; Makanan, Minuman, Komoditi Pertanian dan Perkebunan, Kendaraan dan lainnya. PT. APM bekerjasama dengan produsen penghasil barang untuk menjualkan produk yang dihasilkan di negara yang mempunyai jaringan kerja dengan PT. APM. Saat ini PT. APM telah menjadi agen/ distributor beberapa produk. Dalam melakukan transaksi dengan pihak pembeli/ importir di luar negeri.

PT.Anugerah Pertiwi Mandiri telah mempunyai jaringan kerja dengan para importir maupun eksportir dari negara Russia, Ukrania, Nigeria, Togo, Benin, Ghana, Kanada, Kolombia dan lainnya. Salah satu kiprahnya, PT. Anugerah Pertiwi Mandiri bekerjasama dengan PT. Bali Hai Brewery Indonesia mengekspor minuman Bir ke mitra importir di Russia yaitu DV Trade Llc di kota Vladivostok - Russia.

\section{I Hasil Penelitian - Metode Pembayaran Non L/C}

\section{I.I Advance Payment / Cash Before Delivery/ Pembayaran Dimuka - Proses}

Metode pembayaran ini biasa disebut "dibayar dimuka". Importir/ Pembeli melakukan pembayaran pelunasan terlebih dahulu melalui telegraphic transfer, kartu kredit, atau bahkan pembayaran kontan, sebelum barang dikirimkan, setelah eksportir yakin telah menerima pembayaran, barulah produk yang dibeli di proses pengadaannya dan dikirimkan. Metode pembayaran ini paling sederhana dan paling kecil risikonya bagi Eksportir, tetapi tidak disenangi oleh Importir. Menggunakan metode pembayaran ini harus memberikan keyakinan penuh pada Importir, bahwa Eksportir/ Produsen tidak akan melanggar perjanjian yang disepakati.

Metode pembayaran dimuka, lebih banyak disampaikan oleh eksportir/ penjual, karena Ekpsortir sudah memastikan terjadi transaksi pembelian barang. Metode ini biasanya dilakukan bagi para Eksportir dan Importir yang baru memulai kerjasama/ baru saling mengenal. Proses awal umumnya, pihak Importir/ pembeli mengunjungi pabrik produsen/ Eksportir, secara langsung atau lewat "mitra pihak ketiga" dalam hal ini adalah Perusahaan Perdagangan/ agen dari Importir atau Eksportir.

Pada tahap awal Eksportir harus disiapkan dokumen dan data legalitas perusahaan maupun produk untuk keperluan kerjasama dan di kepabeanan negara Importir seperti; Identitas Perusahaan, Data Spesifikasi Produk, Sertifikat Keselamatan (Untuk produk MaMin), dan lainnya. Dokumen legalitas perusahaan merupakan referensi untuk meyakinkan importir. Dan biasanya setelah proses adminitrasi data dilalui, akan dilanjutkan dengan menandatangani Surat Kontrak atau yang sejenis.

Proses pemesanan diawali dengan Importir mengirimkan Surat Pesanan kepada Eksportir, secara langsung atau melalui mitra pihak ketiga. Setelah Surat Pesanan diterima oleh Importir, maka Importir akan mengirimkan Proforma Invoice yang berupa faktur, menjelaskan ; Jenis Produk, Jumlah, Harga, Bank Account, Estimate Delivery, dan lainnya yang diperlukan sesuai Surat Pesanan kepada Importir. Apabila Importir sudah setuju dengan isi penjelasan pada Proforma Invoice, maka Importir akan menandatangani dan/atau men-stempel Proforma Invoice tersebut sebagai tanda persetujuan, dan mengirimkan kembali kepada Eksportir. Setelah menerima Proforma Invoice yang sudah disetujui, maka Eksportir menyiapkan pesanan.

Diwaktu yang telah disepakati, Importir melakukan transaksi pembayaran yang sesuai nilai pada Proforma Invoice melalui Telegraphic Transfer (TT), Pembayaran melalui TT sangat cepat, dalam tempo \pm 3 hari, dana telah bisa terlihat di bank rekening Eksportir. Setelah pihak Eksportir menerima pembayaran, maka proses pengiriman barang dilakukan. Eksportir melengkapi dokumen ekspor pengiriman barang sesuai dengan ketentuan dan kesepakatan. Pengiriman barang dapat melalui laut atau udara. 
Setelah kapal berangkat, Eksportir mengkompilasi seluruh dokumen ekspor asli yang dibutuhkan di pabean negara Importir. Seluruh dokumen asli dikirimkan kepada Importir melalui kurir. Apabila terjadi masalah dalam pengiriman, misalnya kapal mengalami musibah, maka Importir akan mendapat penggantian materi dari perusahaan Asuransi.

Proses komunikasi diatas umumnya dilakukan melalui email. Dikarenakan komunikasi melalui email, proses ini sangat rentan terjadi penipuan. Pihak lain yang mengetahui proses transaksi ini terjadi, atau para petualang "scammer" dapat meretas alamat email yang digunakan pada komunikasi tersebut.

Faktor yang mendorong dilakukannya pembayaran dengan sistem tunai ini, antara lain :

I. Kepercayaan dari importir kepada eksportir yang sudah cukup baik.

2. Keyakinan yang dimiliki importir terhadap negara eksportir bahwa negara eksportir tidak akan melarang ekspor

3. Pemerintah memberikan izin untuk melakukan pembayaran diawal kepada importir

4. Importir mempunyai likuiditas yang cukup untuk membayar dimuka.

\section{I.I.I Identifikasi Kejadian Yang Tidak Diinginkan}

Pada proses pembayaran dengan metode Advanced Payment/ Cash Before Delivery/ Pembayaran diawal, yang harus diperhatikan secara teliti beberapa hal yang bisa menjadi risiko yaitu ;

I. Eksportir tidak melakukan pengiriman barang yang dibeli oleh Importir.

2. Sarana komunikasi diretas oleh pihak lain, yang memanfaatkan situasi untuk mengalihkan pembayaran oleh importir.

3. Barang yang dikirim oleh eksportir tidak sesuai dengan yang dipesan oleh importir dari sisi jumlah, spesifikasi atau kwalitas.

4. Dokumen ekspor tidak sesuai dengan ketentuan terhadap barang yang diekspor, seperti; jumlah barang, bahan baku yang digunakan, menyebabkan barang tertahan di pelabuhan importir.

5. Barang diterima dalam waktu yang lama, tidak sesuai jadwal yang disepakati.

6. Adanya kemungkinan larangan impor dari negara eksportir.

7. Ketersediaan mata uang asing sebagai alat transaksi pembayaran dan kenaikan nilai kurs.

Tabel 4.I. Kejadian Tidak Diinginkan pada metode pembayaran Advance Payment / Cash Before Delivery/ Pembayaran Dimuka

\begin{tabular}{|c|c|c|c|c|c|}
\hline No. & $\begin{array}{l}\text { Kejadian Tidak } \\
\text { Diinginkan }\end{array}$ & PeluangTerjadi & Dampak & Mitigasi & \\
\hline & & & & Peluang & Dampak \\
\hline $\mathrm{I}$. & $\begin{array}{l}\text { Eksportir tidak } \\
\text { melakukan } \\
\text { pengiriman } \\
\text { barang yang } \\
\text { dibeli oleh } \\
\text { Importir. }\end{array}$ & $\begin{array}{l}\text { I. Jarang Terjadi, karena } \\
\text { sebagian besar } \\
\text { para eksportir ingin } \\
\text { menjaga nama baik, } \\
\text { dan menjalin hubungan } \\
\text { kerja jangka panjang. }\end{array}$ & $\begin{array}{l}\text { 2. Besar, } \\
\text { karena bisa } \\
\text { membuat } \\
\text { kerugian } \\
\text { materi bagi } \\
\text { importir. }\end{array}$ & $\begin{array}{l}\text { I. Mengenal lebih dekatdan } \\
\text { mengetahui kredibilitas } \\
\text { eksportir. } \\
\text { 2. Importir mengunjungi } \\
\text { eksportir ke negara nya } \\
\text { untuk lebih mengenal. } \\
\text { 3. Importir mencari } \\
\text { informasi tentang } \\
\text { eksportir dari Kedutaan } \\
\text { Besar atau Perwakilan } \\
\text { Dagang negaranya. }\end{array}$ & $\begin{array}{l}\text { I. Meminta } \\
\text { Eksportir } \\
\text { membuka } \\
\text { stand by } \\
\text { L/C untuk } \\
\text { melindungi } \\
\text { uang yang } \\
\text { sudah } \\
\text { dibayarkan } \\
\text { importir. }\end{array}$ \\
\hline
\end{tabular}

Sumber:Hasil olahan Penulis 
Tabel 4.2. Kejadian Tidak Diinginkan pada metode pembayaran Advance Payment / Cash Before Delivery/ Pembayaran Dimuka

\begin{tabular}{|c|c|c|c|c|c|}
\hline \multirow[t]{2}{*}{ No. } & \multirow{2}{*}{$\begin{array}{l}\text { Kejadian Tidak } \\
\text { Diinginkan }\end{array}$} & \multirow[t]{2}{*}{ Peluang Terjadi } & \multirow[t]{2}{*}{ Dampak } & \multicolumn{2}{|l|}{ Mitigasi } \\
\hline & & & & Peluang & Dampak \\
\hline 2. & $\begin{array}{l}\text { Sarana } \\
\text { komunikasidiretas oleh } \\
\text { pihak lain (Fraud), yang } \\
\text { memanfaatkan situasi } \\
\text { untuk mengalihkan } \\
\text { pembayaran oleh } \\
\text { importir. }\end{array}$ & $\begin{array}{l}\text { I. Sering terjadi, karena } \\
\text { lemahnya sistem IT, } \\
\text { komputer dapat dibuka } \\
\text { oleh siapa saja, adanya } \\
\text { permainan orang dalam, } \\
\text { transaksi yangbanyak } \\
\text { diketahui orang }\end{array}$ & $\begin{array}{l}\text { I. Besar, sebesar } \\
\text { nilai transaksi } \\
\text { yang disepakati. }\end{array}$ & $\begin{array}{l}\text { I. Memasang software anti retas } \\
\text { pada komputer. } \\
\text { 2. Hanya mengijinkan staf } \\
\text { yang terpercaya yang bisa } \\
\text { mengakses komputer, } \\
\text { khususnya bagian keuangan. } \\
\text { 3. Tidak melakukan perbaikan } \\
\text { komputer pada toko service } \\
\text { yang tidak mewakili merek. } \\
\text { 4. Mengawasi cara kerja staf, } \\
\text { khususnya bagian keuangan. }\end{array}$ & Tidak ada \\
\hline
\end{tabular}

Sumber: Hasil olahan Penulis

Tabel 4.3. Kejadian Tidak Diinginkan pada metode pembayaran Advance Payment / Cash Before Delivery/ Pembayaran Dimuka

\begin{tabular}{|c|c|c|c|c|c|}
\hline \multirow[t]{2}{*}{ No. } & \multirow{2}{*}{$\begin{array}{l}\text { Kejadian Tidak } \\
\text { Diinginkan }\end{array}$} & \multirow[t]{2}{*}{ Peluang Terjadi } & \multirow[t]{2}{*}{ Dampak } & \multicolumn{2}{|l|}{ Mitigasi } \\
\hline & & & & Peluang & Dampak \\
\hline 3. & $\begin{array}{l}\text { Barang yang } \\
\text { dikirimoleh } \\
\text { eksportir tidak } \\
\text { sesuai dengan } \\
\text { yang dipesan oleh } \\
\text { importir dari sisi } \\
\text { jumlah, spesifikasi } \\
\text { atau kwalitas. }\end{array}$ & $\begin{array}{l}\text { I. Jarang Terjadi, } \\
\text { karena sebagian } \\
\text { besarpara } \\
\text { eksportir } \\
\text { ingin menjaga } \\
\text { nama baik, } \\
\text { dan menjalin } \\
\text { hubungan kerja } \\
\text { jangka panjang. }\end{array}$ & $\begin{array}{l}\text { I. Besar, karena } \\
\text { Importir } \\
\text { mengalami } \\
\text { kerugian, tidak } \\
\text { bisa segera } \\
\text { menjual. } \\
\text { 2. Besar, mengakibat } \\
\text { reputasi Importir } \\
\text { menurun karena } \\
\text { tidak bisa } \\
\text { memasok barang } \\
\text { ke pasar ritel. }\end{array}$ & $\begin{array}{l}\text { I. Pada Proforma } \\
\text { invoice, importir harus } \\
\text { memeriksa sedetil- } \\
\text { detilnya yang tertulis } \\
\text { seperti; jumlah, spesifikasi, } \\
\text { kwalitas, sesuai dengan } \\
\text { produk yang ditawarkan } \\
\text { oleh ekportir pada tahap } \\
\text { awal. } \\
\text { 2. Menyerahkan kepada } \\
\text { surveyor independen } \\
\text { untuk melakukan } \\
\text { pemeriksaan barang. }\end{array}$ & $\begin{array}{l}\text { I. Dalam perjanjian/ } \\
\text { surat pesanan } \\
\text { dicantumkan klasul } \\
\text { yang apabila hal } \\
\text { tersebut terjadi, } \\
\text { maka ekspotir } \\
\text { harus mendapatkan } \\
\text { sangsi yang } \\
\text { disepakati. }\end{array}$ \\
\hline
\end{tabular}

Sumber : Hasil olahan Penulis

Tabel 4.4. Kejadian Tidak Diinginkan pada metode pembayaran Advance Payment / Cash Before Delivery/ Pembayaran Dimuka

\begin{tabular}{|c|c|c|c|c|c|}
\hline No. & $\begin{array}{l}\text { Kejadian Tidak } \\
\text { Diinginkan }\end{array}$ & $\begin{array}{l}\text { PeluangTerja- } \\
\text { di }\end{array}$ & Dampak & Mitigasi & \\
\hline & & & & Peluang & Dampak \\
\hline 4. & $\begin{array}{l}\text { Dokumen } \\
\text { ekspor tidak sesuai } \\
\text { dengan ketentuan } \\
\text { terhadap barang } \\
\text { yang diekspor, } \\
\text { seperti; jumlah } \\
\text { barang, bahan baku } \\
\text { yang digunakan, } \\
\text { menyebabkan barang } \\
\text { tertahan di pelabuhan } \\
\text { importir. }\end{array}$ & $\begin{array}{l}\text { I. Jarang terjadi, } \\
\text { karena } \\
\text { keteledoran } \\
\text { Eksportir dan/ } \\
\text { atau adanya } \\
\text { perubahan } \\
\text { kebijakan di } \\
\text { kepabeanan } \\
\text { di negara } \\
\text { Importir. }\end{array}$ & $\begin{array}{l}\text { 1. Besar, barang yang } \\
\text { di import tidak bisa } \\
\text { dikeluarkan dari pabean } \\
\text { di negara importir. } \\
\text { 2. Besar biaya demorage/ } \\
\text { sewa gudang akibat dari } \\
\text { tertundanya barang } \\
\text { keluar. }\end{array}$ & $\begin{array}{l}\text { I. Eksportir terlebih dahulu } \\
\text { mengirimkanhasil scaan/ copy } \\
\text { dokumen ekspor kepada } \\
\text { Importir. } \\
\text { 2. Importir memeriksadokumen } \\
\text { ekspor tersebut. } \\
\text { 3. Importir segera } \\
\text { memberitahukan eksportir } \\
\text { apabila ada perubahan kebijakan } \\
\text { di negara importir. }\end{array}$ & Tidak ada \\
\hline
\end{tabular}


Sumber: Hasil olahan Penulis

Tabel 4.5. Kejadian Tidak Diinginkan pada metode pembayaran Advance Payment / Cash Before Delivery/ Pembayaran Dimuka

\begin{tabular}{|c|c|c|c|c|c|}
\hline \multirow[t]{2}{*}{ No. } & \multirow{2}{*}{$\begin{array}{l}\text { Kejadian Tidak } \\
\text { Diinginkan }\end{array}$} & \multirow[t]{2}{*}{ PeluangTerjadi } & \multirow[t]{2}{*}{ Dampak } & \multicolumn{2}{|l|}{ Mitigasi } \\
\hline & & & & Peluang & Dampak \\
\hline 5. & $\begin{array}{l}\text { Barang } \\
\text { diterima dalam } \\
\text { waktu yang lama, } \\
\text { tidak sesuai } \\
\text { jadwal yang } \\
\text { disepakati. }\end{array}$ & $\begin{array}{l}\text { I. Sering terjadi, karena } \\
\text { terjadi beberapa kendala } \\
\text { pada eksportir seperti; } \\
\text { kesulitan mendapatkan } \\
\text { bahan baku, kerusakan alat } \\
\text { produksi, jadwal pengapalan, } \\
\text { dan lainnya. }\end{array}$ & $\begin{array}{l}\text { I. Besar, karena } \\
\text { kerugian bagi } \\
\text { importir, tidak bisa } \\
\text { segera menjual/ } \\
\text { menggunakan } \\
\text { produk yang } \\
\text { dipesan. }\end{array}$ & $\begin{array}{l}\text { I. Importir } \\
\text { mencari } \\
\text { eksportir } \\
\text { yang } \\
\text { kredibel. }\end{array}$ & $\begin{array}{l}\text { I. Importir memperoleh jadwal } \\
\text { produksi pesanannya. } \\
\text { 2. Importir harus rajin berkomu- } \\
\text { nikasi dengan eksportir untuk } \\
\text { mengecek pesanan. } \\
\text { 3. Mengenakan sangsi denda } \\
\text { kepada eksportir. }\end{array}$ \\
\hline
\end{tabular}

Sumber: Hasil olahan Penulis

Tabel 4.6. Kejadian Tidak Diinginkan pada metode pembayaran Advance Payment / Cash Before Delivery/ Pembayaran Dimuka

\begin{tabular}{|c|c|c|c|c|c|}
\hline \multirow[t]{2}{*}{ No. } & \multirow{2}{*}{$\begin{array}{l}\text { Kejadian Tidak } \\
\text { Diinginkan }\end{array}$} & \multirow[t]{2}{*}{ PeluangTerjadi } & \multirow[t]{2}{*}{ Dampak } & \multicolumn{2}{|l|}{ Mitigasi } \\
\hline & & & & Peluang & Dampak \\
\hline 6. & $\begin{array}{l}\text { Adanya } \\
\text { kemungkinan } \\
\text { larangan } \\
\text { mengimpor } \\
\text { dari negara } \\
\text { eksportir. }\end{array}$ & $\begin{array}{l}\quad \text { I. Jarang terjadi, } \\
\text { karena sudah ada } \\
\text { Peraturan dan } \\
\text { Ketentuan yang } \\
\text { dikeluarkan oleh } \\
\text { pemerintah, kecuali } \\
\text { ada terjadi persoalan } \\
\text { ekonomi, politik, } \\
\text { perang dagang (trade } \\
\text { war). }\end{array}$ & $\begin{array}{l}\text { I. Besar, Importir } \\
\text { tidakbisa } \\
\text { menerima produk } \\
\text { yang dipesan. } \\
\text { 2. Besar, Kerugian } \\
\text { bagi importir } \\
\text { yang membuat } \\
\text { perjanjian } \\
\text { pembelian untuk } \\
\text { jangka panjang. }\end{array}$ & $\begin{array}{l}\text { I. Importir selalu } \\
\text { memonitor kebijakan } \\
\text { kebijakan pemerintah. } \\
\text { 2. Eksportir bergabung } \\
\text { di Kamar Dagang dam } \\
\text { Industri, Asosiasi yang } \\
\text { berhubungan dengan } \\
\text { kegiatan usaha. } \\
\text { 3. Tidak membuat } \\
\text { perjanjian pembelian } \\
\text { jangka panjang. }\end{array}$ & $\begin{array}{l}\text { 4. Mempelajari } \\
\text { situasi } \\
\text { ekonomi } \\
\text { dan politik } \\
\text { negara } \\
\text { eksportir. }\end{array}$ \\
\hline
\end{tabular}

Sumber : Hasil olahan Penulis

Tabel 4.7 Kejadian Tidak Diinginkan pada metode pembayaran Advance Payment / Cash Before Delivery/ Pembayaran Dimuka

\begin{tabular}{|c|c|c|c|c|c|}
\hline \multirow[t]{2}{*}{ No. } & \multirow{2}{*}{$\begin{array}{l}\text { Kejadian Tidak } \\
\text { Diinginkan }\end{array}$} & \multirow[t]{2}{*}{ PeluangTerjadi } & \multirow[t]{2}{*}{ Dampak } & \multicolumn{2}{|c|}{ Mitigasi } \\
\hline & & & & Peluang & Dampak \\
\hline 7. & $\begin{array}{l}>\quad \text { Ketersediaan mata } \\
\text { uangasing sebagai alat } \\
\text { transaksi pembayaran dan } \\
\text { kenaikan nilai kurs. }\end{array}$ & $\begin{array}{l}\text { I. Jarang terjadi, } \\
\text { karenaperan } \\
\text { pemerintah untuk } \\
\text { menjaga kestabilan } \\
\text { perekonomian. } \\
\text { Kecuali ada gejolak } \\
\text { perekonomian } \\
\text { domestik atau } \\
\text { internasional. }\end{array}$ & $\begin{array}{l}\text { I. Besar, Pembayaran } \\
\text { kepada eksportir } \\
\text { menjadi tertunda, } \\
\text { yang mengakibatkan } \\
\text { pesanan tertunda } \\
\text { juga. } \\
\text { 2. Kerugian bagi } \\
\text { importir karena nilai } \\
\text { kurs naik. }\end{array}$ & $\begin{array}{l}\text { I. Importir } \\
\text { harus selalu } \\
\text { mempelajari } \\
\text { dan mengikuti } \\
\text { perkembangan } \\
\text { dan situasi } \\
\text { ekonomi di } \\
\text { negaranya. }\end{array}$ & $\begin{array}{l}\text { I. Importir } \\
\text { melakukan } \\
\text { "hedging" } \\
\text { untuk menjaga } \\
\text { ketersediaan } \\
\text { mata uang untuk } \\
\text { pembayaran. }\end{array}$ \\
\hline
\end{tabular}

Sumber: Hasil olahan Penulis

Catatan : "Hedging” adalah strategi trading untuk "membatasi” atau "melindungi” dana trader dari fluktuasi nilai tukar mata uang yangtidak menguntungkan. “Hedging” memberi kesempatan bagi trader untuk melindungi diri dari kemungkinan rugi (loss) meski ia tengahmelakukan transaksi. 
Tabel 4.8 Pengukuran Skoring Risiko pada metode pembayaran AdvancePayment / Cash Before Delivery/ Pembayaran Dimuka

\begin{tabular}{|c|c|c|c|c|c|c|}
\hline No & Kejadian Tidak Diinginkan & Peluang & $\begin{array}{l}\text { Skala Peluang } \\
\quad 1-5\end{array}$ & Dampak & $\begin{array}{c}\text { Skala } \\
\text { Dampak I - } 5\end{array}$ & Risiko \\
\hline I & $\begin{array}{l}\text { Eksportir tidak melakukan pengiriman barang } \\
\text { yang dibeli oleh } \\
\text { Importir. }\end{array}$ & Jarang Terjadi & 2 & Besar & 5 & 10 \\
\hline 2 & $\begin{array}{l}\text { Sarana komunikasi diretas oleh pihak lain, } \\
\text { yang memanfaatkan situasi untuk mengalihkan } \\
\text { pembayaran oleh importir. }\end{array}$ & Jarang Terjadi & 4 & Besar & 5 & 20 \\
\hline 3 & $\begin{array}{l}\text { Barang yang dikirim oleh eksportir tidak sesuai } \\
\text { dengan yang dipesan oleh importirdari sisi } \\
\text { jumlah, spesifikasi atau } \\
\text { kwalitas. }\end{array}$ & Jarang Terjadi & 2 & Besar & 4 & 8 \\
\hline 4 & $\begin{array}{l}\text { Dokumen ekspor tidaksesuai dengan ketentuan } \\
\text { terhadap barang yang diekspor, seperti; jumlah } \\
\text { barang, bahan baku yang } \\
\text { digunakan, menyebabkan barang tertahan di } \\
\text { pelabuhan importir. }\end{array}$ & Jarang Terjadi & 2 & Besar & 4 & 8 \\
\hline 5 & $\begin{array}{l}\text { Barang diterima dalam waktu yang lama, tidak } \\
\text { sesuai jadwal yang disepakati. }\end{array}$ & Jarang Terjadi & 3 & Besar & 5 & 15 \\
\hline 6 & $\begin{array}{l}\text { Adanya kemungkinan larangan mengimpor } \\
\text { dari negara eksportir }\end{array}$ & Jarang Terjadi & 2 & Besar & 4 & 8 \\
\hline 7 & $\begin{array}{l}\text { Ketersediaan mata uang sebagai alat transaksi } \\
\text { pembayaran dan kenaikan nilai kurs. }\end{array}$ & Jarang Terjadi & 2 & Besar & 4 & 8 \\
\hline
\end{tabular}

Sumber: Hasil olahan Penulis

Heat Map ;Metode pembayaran Advance Payment / Cash Before Delivery/Pembayaran Dimuka

\subsubsection{Open Account / Cash on Delivery/ Pembayaran Kemudian - Proses}

Metode pembayaran ini adalah kebalikan dari metode pembayaran Advance Payment / Cash Before Delivery/ Pembayaran Dimuka. Pada metode ini Eksportir terlebih dahulu mengirimkan barangnya, setelah itu Importir/ Pembeli melakukan pembayaran pelunasan setelah menerima barang pesanan atau setidaknya barang sudah dikirimkan/ diberangkatkan oleh ekposrtir dengan mengirimkan copy dokumen ekspor terlebih dahulu. Pembayaran umumnya melalui telegraphic transfer, kartu kredit, atau bahkan pembayaran kontan, sangat tergantung pada hasil negosiasi. Risiko risiko yang kemungkinan akan terjadi hampir sama dengan risiko yang ada pada metode pembayaran advance payment, tetapi untuk metode ini risiko lebih besar ada pada ekportir.

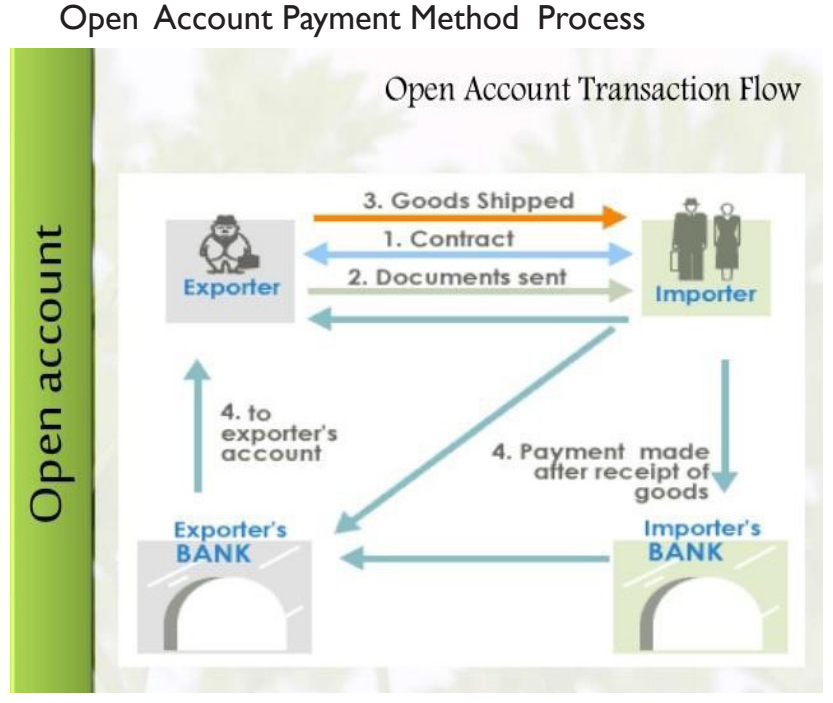

Gambar 4.1 : Open Account Payment Method 
Faktor yang mendorong dilakukannya pembayaran dengan sistem cash ondelivery ini, antara lain :

I. Kepercayaan dari eksportir kepada importir yang sudah cukup baik, yang sudah saling mengenal.

2. Keyakinan yang dimiliki eksportir terhadap negara importir bahwa negara importir tidak akan melarang import terhadap barang yang dijual.

3. Eksportir mempunyai likuiditas yang cukup untuk memproduksi pesananimportir.

\section{I.2. I Identifikasi Kejadian Yang Tidak Diinginkan}

Pada proses pembayaran dengan metode Open Account/ Cash on Delivery/ Pembayaran Kemudian, yang harus diperhatikan secara teliti beberapa hal yang bisa menjadi risiko yaitu ;

I. Importir melakukan wanprestasi, tidak melakukan pembayaran.

2. Barang yang diterima importir tidak sesuai dengan yang dipesan dari sisi jumlah, spesifikasi atau kwalitas.

3. Dokumen ekspor tidak sesuai dengan ketentuan terhadap barang yang diekspor, seperti; jumlah barang, bahan baku yang digunakan, menyebabkan barang tertahan di pelabuhan importir.

4. Barang yang di kirimkan terlambat diterima oleh importir.

5. Adanya kemungkinan larangan mengekspor ke negara importir secara tiba-tiba yang diakibatkan kejadian politik, perang dagang.

Tabel 4.9. Kejadian Tidak Diinginkan pada metode pembayaran Open Account / Cash on Delivery/ Pembayaran Kemudian

\begin{tabular}{|c|c|c|c|c|c|}
\hline \multirow[t]{2}{*}{ No. } & \multirow{2}{*}{$\begin{array}{l}\text { Kejadian Tidak } \\
\text { Diinginkan }\end{array}$} & \multirow[t]{2}{*}{ PeluangTerjadi } & \multirow[t]{2}{*}{ Dampak } & \multicolumn{2}{|l|}{ Mitigasi } \\
\hline & & & & Peluang & Dampak \\
\hline I. & $\begin{array}{l}\text { Importir } \\
\text { melakukan wanprestasi, } \\
\text { tidak melakukan } \\
\text { pembayaran. }\end{array}$ & $\begin{array}{l}\text { I. Jarang Terjadi, } \\
\text { karena sebagian besar } \\
\text { para importir ingin } \\
\text { menjaga reputasi yang } \\
\text { baik, dan menjalin } \\
\text { hubungan kerja jang- } \\
\text { ka panjang. }\end{array}$ & $\begin{array}{l}\text { I. Besar, karena bisa } \\
\text { membuat keru- } \\
\text { gian materi bagi } \\
\text { eksportir. }\end{array}$ & $\begin{array}{l}\text { 1. Mengenal lebih dekatdan } \\
\text { mengetahui kredibilitas importir. } \\
\text { 2. Eksportir mengunjungi im- } \\
\text { portir ke negara nya untuk lebih } \\
\text { mengenal. } \\
\text { 3. Eksportir mencari informasi } \\
\text { tentang importir dari Kedutaan } \\
\text { Besar atau Perwakilan } \\
\text { Dagang negaranya. }\end{array}$ & Tidak ada \\
\hline
\end{tabular}

Sumber : Hasil olahan Penulis

Tabel 4. I0 Kejadian Tidak Diinginkan pada metode pembayaran Open Account / Cash on Delivery/ Pembayaran Kemudian

\begin{tabular}{|l|l|l|l|l|l|}
\hline No. & $\begin{array}{l}\text { Kejadian Tidak } \\
\text { Diinginkan }\end{array}$ & \multicolumn{1}{|c|}{ PeluangTerjadi } & Dampak & \multicolumn{2}{|c|}{ Mitigasi } \\
\hline Dampak \\
\hline 2. & $\begin{array}{l}\text { diterima importir } \\
\text { tidak sesuaidengan } \\
\text { yang dipesan dari sisi } \\
\text { jumlah, } \\
\text { spesifikasi } \\
\text { ataukwalitas. }\end{array}$ & $\begin{array}{l}\text { I. Jarang Terjadi, karena } \\
\text { sebagian besarpara } \\
\text { eksportir ingin menjaga } \\
\text { nama baik, dan menjalin } \\
\text { hubungan kerja } \\
\text { jangka panjang. }\end{array}$ & $\begin{array}{l}\text { I. Besar, berakibat } \\
\text { kepada reputasi } \\
\text { Eksportir jadi } \\
\text { menurun karena } \\
\text { tidak bisa menjaga } \\
\text { kwalitas barang. }\end{array}$ & $\begin{array}{l}\text { I. Eksportir harus melakukan } \\
\text { Quality Control dan Quality } \\
\text { Assurance. }\end{array}$ & Tidak ada \\
\hline
\end{tabular}

Sumber: Hasil olahan Penulis 
Tabel 4.I I. Kejadian Tidak Diinginkan pada metode pembayaran Open Account / Cash on Delivery/ Pembayaran Kemudian

\begin{tabular}{|l|l|l|l|l|l|}
\hline No. & $\begin{array}{l}\text { Kejadian Tidak } \\
\text { Diinginkan }\end{array}$ & \multicolumn{1}{|c|}{ PeluangTerjadi } & Dampak & \multicolumn{2}{|c|}{ Peluang } \\
\hline 3. & $\begin{array}{l}\text { Dokmpak } \\
\text { tidak sesuai dengan } \\
\text { ketentuan terhadap } \\
\text { barang yang diekspor, } \\
\text { seperti; jumlah barang, } \\
\text { bahan baku yang } \\
\text { digunakan, menyebabkan } \\
\text { barang tertahan di } \\
\text { pelabuhan importir. }\end{array}$ & $\begin{array}{l}\text { I. Jarang terjadi, karena } \\
\text { keteledoran Eksportir } \\
\text { dan/atau adanya } \\
\text { perubahan kebijakan di } \\
\text { kepabeanan di negara } \\
\text { Importir. }\end{array}$ & $\begin{array}{l}\text { 1. Besar, barang yang } \\
\text { di import tidak bisa } \\
\text { dikeluarkan dari pabean } \\
\text { di negara importir. } \\
\text { 2. Besar biaya } \\
\text { demorage/ sewa gudang } \\
\text { akibat dari tertundanya } \\
\text { barang keluar. }\end{array}$ & $\begin{array}{l}\text { Eksportir terlebih } \\
\text { dahulu mengirimkan } \\
\text { hasil scaan/ copy } \\
\text { dokumen ekspor } \\
\text { kepada Importir. } \\
\text { 2. Importir } \\
\text { memeriksa dokumen } \\
\text { ekspor tersebut. } \\
\text { 3. Importir segera } \\
\text { memberitahukan } \\
\text { eksportir apabila ada } \\
\text { perubahan kebijakan } \\
\text { di negara importir. }\end{array}$ \\
\hline
\end{tabular}

Sumber: Hasil olahan Penulis

Tabel 4. 12. Kejadian Tidak Diinginkan pada metode pembayaran Open Account / Cash on Delivery/ Pembayaran Kemudian

\begin{tabular}{|c|c|c|c|c|c|}
\hline \multirow[t]{2}{*}{ No. } & \multirow{2}{*}{$\begin{array}{l}\text { Kejadian Tidak Diing- } \\
\text { inkan }\end{array}$} & \multirow[t]{2}{*}{ Peluang Terjadi } & \multirow[t]{2}{*}{ Dampak } & \multicolumn{2}{|c|}{ Mitigasi } \\
\hline & & & & Peluang & Dampak \\
\hline 4.. & $\begin{array}{l}\text { Barang yang di } \\
\text { kirimkan terlambat } \\
\text { diterima oleh importir. }\end{array}$ & $\begin{array}{l}\text { I. Sering terjadi, karena } \\
\text { terjadi beberapa } \\
\text { kendala pada ekspor- } \\
\text { tir seperti; kesulitan } \\
\text { mendapatlkan bahan } \\
\text { baku, kerusakan alat } \\
\text { produksi, jadwal penga- } \\
\text { palan, dan lainnya. }\end{array}$ & $\begin{array}{l}\text { I. Besar, karena kerugian } \\
\text { bagi eksportir, tidak bisa } \\
\text { segera mendapatkan } \\
\text { pembayaran. }\end{array}$ & $\begin{array}{l}\text { 1. Eksportir harus } \\
\text { menyiapkan sarana } \\
\text { produksi yang baik. } \\
2 \text {. Mencari } \\
\text { forwarding yang } \\
\text { kredibel., }\end{array}$ & Tidak ada \\
\hline
\end{tabular}

Sumber: Hasil olahan Penulis

Tabel 4. 13. Kejadian Tidak Diinginkan pada metode pembayaran Open Account / Cash on Delivery/ Pembayaran Kemudian

\begin{tabular}{|c|c|c|c|c|c|}
\hline \multirow[t]{2}{*}{ No. } & \multirow{2}{*}{$\begin{array}{l}\text { Kejadian Tidak } \\
\text { Diinginkan }\end{array}$} & \multirow[t]{2}{*}{ PeluangTerjadi } & \multirow[t]{2}{*}{ Dampak } & \multicolumn{2}{|c|}{ Mitigasi } \\
\hline & & & & Peluang & Dampak \\
\hline 5. & $\begin{array}{l}\text { Adanya } \\
\text { kemungkinan larangan } \\
\text { mengekspor ke negara } \\
\text { importir secara tiba-tiba } \\
\text { yang diakibatkan kejadian } \\
\text { politik, perang dagang. }\end{array}$ & $\begin{array}{l}\text { I. Jarang terjadi, karena } \\
\text { sudah ada Peraturan } \\
\text { dan Ketentuan yang } \\
\text { dikeluarkan oleh } \\
\text { pemerintah, kecuali } \\
\text { ada terjadi persoalan } \\
\text { ekonomi, politik. }\end{array}$ & $\begin{array}{l}\text { I. Besar, Eksportir telah } \\
\text { memproduksi barang, tetapi } \\
\text { tidak bisa mengirimkan ke } \\
\text { negara importir. produk } \\
\text { yang dipesan. }\end{array}$ & Tidak ada & $\begin{array}{l}\text { I. Menjual } \\
\text { produk } \\
\text { ke negara } \\
\text { lain dan/ } \\
\text { atau pasar } \\
\text { domestik. }\end{array}$ \\
\hline
\end{tabular}

Sumber :Hasil olahan Penulis 
Tabel 4.I4 Pengukuran Skoring Risiko pada metode pembayaran Open Account / Cash on Delivery/ Pembayaran Kemudian

\begin{tabular}{|c|c|c|c|c|c|c|}
\hline No & Kejadian Tidak Diinginkan & Peluang & $\begin{array}{l}\text { Skala Pelu- } \\
\text { ang I - } 5\end{array}$ & Dampak & $\begin{array}{c}\text { Skala } \\
\text { Dampak } \\
\text { I - } 5\end{array}$ & Risiko \\
\hline I & $\begin{array}{l}\text { Importir melakukan wanprestasi, tidak melakukan } \\
\text { pembayaran. }\end{array}$ & Jarang Terjadi & 2 & Besar & 5 & 10 \\
\hline 2 & $\begin{array}{l}\text { Barang yang diterima importir tidak sesuai dengan } \\
\text { yang dipesan dari sisi jumlah, spesifikasi atau } \\
\text { kwalitas. }\end{array}$ & Jarang Terjadi & 1 & Besar & 4 & 4 \\
\hline 3 & $\begin{array}{l}\text { Dokumen ekspor tidaksesuai dengan ketentuan } \\
\text { terhadap barang yang diekspor, seperti; jumlah } \\
\text { barang, bahan baku yang digunakan, menyebabkan } \\
\text { barang tertahan di pelabuhan } \\
\text { importir. }\end{array}$ & Jarang Terjadi & 2 & Besar & 4 & 8 \\
\hline 4 & $\begin{array}{l}\text { Barang yang di kirimkan terlambat diterima oleh } \\
\text { importir. }\end{array}$ & $\begin{array}{l}\text { Sering } \\
\text { Terjadi }\end{array}$ & 3 & Besar & 5 & 15 \\
\hline 5 & $\begin{array}{l}\text { Adanya kemungkinan larangan mengeksporke } \\
\text { negara importir secara tiba-tiba yang diakibatkan } \\
\text { kejadian politik, perang dagang. }\end{array}$ & Jarang Terjadi & 2 & Besar & 4 & 8 \\
\hline
\end{tabular}

Sumber: Hasil olahan Penulis

\subsubsection{Collection Payment - Against Document - Proses}

Metode Collection Payment - Against Document lebih sering digunakan oleh para eksportir dan importir yang melakukan transaksi nilai sedang.

Metode ini sering digunakan juga oleh para eksportir dan importir yang baru saling mengenal, dimana tahap ini dapat dikatakan proses untuk membangun kepercayaan/ saling percaya. Metode ini dirasakan memiliki risiko yang sama bagi eksportir dan importir, walaupun importir lebih memiliki risiko, ketimbang eksportir.

Pada metode ini, importir dipersyaratkan untuk membayar tanda jadi (down payment) sekitar $30 \%$ s/d $40 \%$ dari dari nilai pesanan, ini merupakan wujud keseriusan importir dalam menjalin kerjasama.

Kejadian yang tidak diinginkan relatif sama dengan metode pembayaran Advance Payment atau Cash on Delivery.

Against Document Payment Method Process

\section{I.3.I Identifikasi Kejadian Yang Tidak Diinginkan;}

I. Barang yang dikirimkan tidak sesuai dengan pesanan importir .

2. Pembayaran pelunasan tidak dibayarkan oleh importir.
3. Jadwal pengiriman pesanan mundur.

4. Dokumen ekspor tidak sesuai dengan ketentuan di negara importir.

Gambar 4.2 :Against Document Payment Method

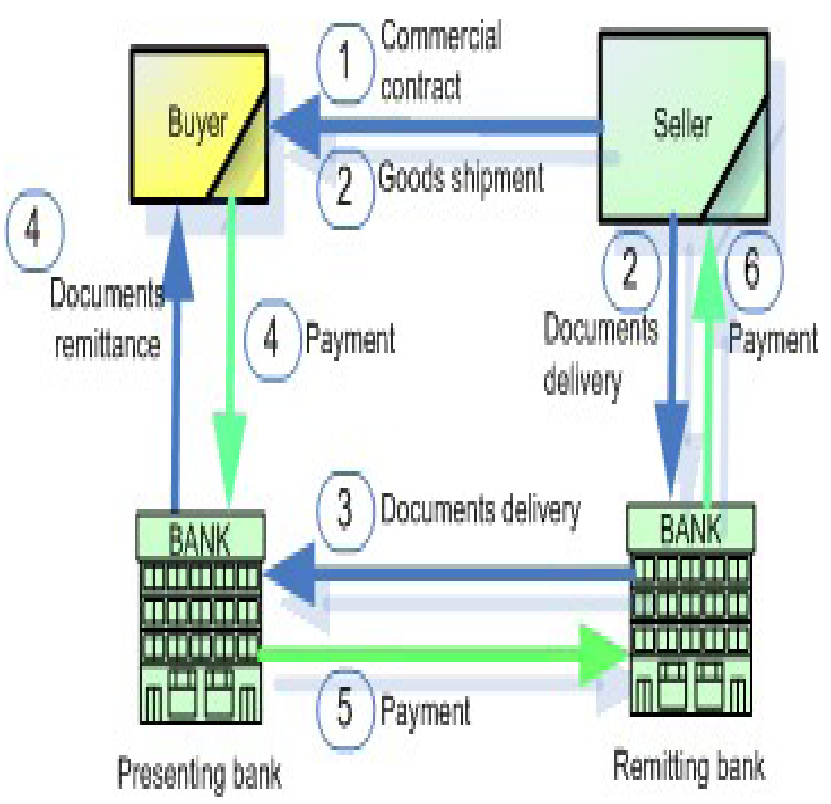


Tabel 4.15 Kejadian Tidak Diinginkan pada metode pembayaran Collection Payment - Against Document

\begin{tabular}{|c|c|c|c|c|c|}
\hline \multirow[t]{2}{*}{ No. } & \multirow{2}{*}{$\begin{array}{l}\text { Kejadian Tidak } \\
\text { Diinginkan }\end{array}$} & \multirow[t]{2}{*}{ PeluangTerjadi } & \multirow[t]{2}{*}{ Dampak } & \multicolumn{2}{|l|}{ Mitigasi } \\
\hline & & & & Peluang & Dampak \\
\hline $\mathrm{I}$. & $\begin{array}{l}\text { Barang yang } \\
\text { dikirimkan tidak } \\
\text { sesuai dengan } \\
\text { pesanan importir. }\end{array}$ & $\begin{array}{l}\text { I. Jarang Terjadi, karena } \\
\text { sebagian besar para } \\
\text { eksportir ingin menjaga } \\
\text { nama baik, dan menjalin } \\
\text { hubungan kerja jangka } \\
\text { panjang. }\end{array}$ & $\begin{array}{l}\text { I. Besar, Importir } \\
\text { mengalami kerugian, } \\
\text { tidak bisa segera } \\
\text { menjual produk yang } \\
\text { telah di impor. }\end{array}$ & $\begin{array}{l}\text { I. Pada Proforma invoice, } \\
\text { eksportir harus memeriksa } \\
\text { sedetil-detilnya yang } \\
\text { tertulis seperti; jumlah, } \\
\text { spesifikasi,kwalitas, sesuai } \\
\text { dengan produk yang } \\
\text { ditawarkan oleh ekportir } \\
\text { pada tahap awal. } \\
\text { 2. Menyerahkan kepada } \\
\text { surveyor independen untuk } \\
\text { melakukan pemeriksaan } \\
\text { barang. }\end{array}$ & $\begin{array}{l}\text { I. Dalam } \\
\text { perjanjian / } \\
\text { surat pesanan } \\
\text { dicantumkan } \\
\text { klasul yang } \\
\text { apabila hal } \\
\text { tersebut } \\
\text { terjadi, maka } \\
\text { ekspotir harus } \\
\text { mendapatkan } \\
\text { sangsi yang } \\
\text { disepakati. }\end{array}$ \\
\hline
\end{tabular}

Sumber :Hasil olahan Penulis

Tabel 4.I 6 Kejadian Tidak Diinginkan pada metode pembayaran Collection Payment - Against Document

\begin{tabular}{|c|l|l|l|l|l|}
\hline No. & $\begin{array}{l}\text { Kejadian Tidak } \\
\text { Diinginkan }\end{array}$ & Peluang Terjadi & \multicolumn{1}{|c|}{ Dampak } & \multicolumn{2}{|c|}{ Pampakigasi } \\
\hline 2. & $\begin{array}{l}\text { Dembayaran } \\
\text { pelunasan oleh } \\
\text { importir. }\end{array}$ & $\begin{array}{l}\text { I.Jarang terjadi, } \\
\text { kesiapan cash flow } \\
\text { importir yang baik. }\end{array}$ & $\begin{array}{l}\text { I. Besar, Eksportir } \\
\text { tidak akan } \\
\text { mengirimkan } \\
\text { pesanan. Importir } \\
\text { tidak bisa menerima } \\
\text { barang pesanannya }\end{array}$ & $\begin{array}{l}\text { I. Importir harus menyiapkan } \\
\text { pendanaan yangselalu } \\
\text { tersedia sesuai rencana } \\
\text { penerimaan dan } \\
\text { pembayaran. } \\
\text { 2. Tersedia dana cadangan } \\
\text { untuk mengatasi arus kas } \\
\text { yang macet. }\end{array}$ & $\begin{array}{l}\text { I. Importir } \\
\text { menegosiasikan dengan } \\
\text { eksportir untuk } \\
\text { cara pembayaran } \\
\text { pelunasan. }\end{array}$ \\
\hline
\end{tabular}

Sumber : Hasil olahan Penulis

Tabel 4. I7. Kejadian Tidak Diinginkan pada metode pembayaran Collection Payment - Against Document

\begin{tabular}{|c|l|l|l|l|l|}
\hline No. & $\begin{array}{l}\text { Kejadian Tidak } \\
\text { Diinginkan }\end{array}$ & \multicolumn{1}{|c|}{ Peluang Terjadi } & \multicolumn{1}{|c|}{ Dampak } & \multicolumn{2}{|c|}{ Peluang } \\
\hline & & & & \multicolumn{2}{|c|}{ Dampak } \\
\hline 3. & $\begin{array}{l}\text { pengiriman pesanan } \\
\text { mundur. }\end{array}$ & $\begin{array}{l}\text { 2.Sering terjadi, karena } \\
\text { terjadi beberapa kendala } \\
\text { pada eksportir seperti; } \\
\text { kesulitan mendapatkan } \\
\text { bahan baku, kerusakan } \\
\text { alat produksi, jadwal } \\
\text { pengapalan, dan lainnya.. }\end{array}$ & $\begin{array}{l}\text { I. Besar, Importir } \\
\text { tidak bisa } \\
\text { menerima barang } \\
\text { pesanannya sesuai } \\
\text { waktunya, yang } \\
\text { bisa mengakibatkan } \\
\text { stok barang habis. } \\
\text { 2. Besar, karena } \\
\text { Importir sudah } \\
\text { membayar uang } \\
\text { tanda pesan (down } \\
\text { payment). }\end{array}$ & $\begin{array}{l}\text { I. Importir harus mempunyai } \\
\text { beberapa sumber produsen } \\
\text { lain yang bisa mengerjakan } \\
\text { pesanannya. }\end{array}$ & $\begin{array}{l}\text { I. Dalam } \\
\text { perjanjian / } \\
\text { surat pesanan } \\
\text { dicantumkan } \\
\text { klasul yang } \\
\text { apabila hal } \\
\text { tersebut } \\
\text { terjadi, maka } \\
\text { ekspotir harus } \\
\text { mendapatkan } \\
\text { sangsi yang } \\
\text { disepakati. }\end{array}$ \\
\hline
\end{tabular}


Tabel 4. 18. Kejadian Tidak Diinginkan pada metode pembayaran Collection Payment - Against Documen

\begin{tabular}{|c|c|c|c|c|c|}
\hline \multirow[t]{2}{*}{ No. } & \multirow{2}{*}{$\begin{array}{l}\text { Kejadian Tidak } \\
\text { Diinginkan }\end{array}$} & \multirow[t]{2}{*}{ PeluangTerjadi } & \multirow[t]{2}{*}{ Dampak } & \multicolumn{2}{|l|}{ Mitigasi } \\
\hline & & & & Peluang & Dampak \\
\hline 4. & $\begin{array}{l}\text { Dokumen } \\
\text { ekspor tidak sesuai } \\
\text { dengan ketentuan } \\
\text { di negara importir. }\end{array}$ & $\begin{array}{l}\text { I. Jarang terjadi, } \\
\text { karena } \\
\text { keteledoran } \\
\text { Eksportir dan/atau } \\
\text { adanya perubahan } \\
\text { kebijakan di } \\
\text { kepabeanan di } \\
\text { negara Importir. }\end{array}$ & $\begin{array}{l}\text { 1. Besar, barang yang } \\
\text { diimport tidak bisa } \\
\text { dikeluarkan dari } \\
\text { pabean di negara } \\
\text { importir. } \\
\text { 2. Besar biaya demorage/ } \\
\text { sewa gudang akibat } \\
\text { dari tertundanya } \\
\text { barang keluar. }\end{array}$ & $\begin{array}{l}\text { I. Eksportir terlebih dahulu } \\
\text { mengirimkan hasil scaan/ copy } \\
\text { dokumen ekspor kepada } \\
\text { Importir. } \\
\text { 2. Importir memeriksa dokumen } \\
\text { ekspor tersebut. } \\
\text { 3. Importir segera } \\
\text { memberitahukan eksportir } \\
\text { apabila ada perubahan } \\
\text { kebijakan di negara importir. }\end{array}$ & $\begin{array}{l}\text { I. Mengenakan } \\
\text { sangsi denda } \\
\text { kepada } \\
\text { eksportir }\end{array}$ \\
\hline
\end{tabular}

Sumber :Hasil olahan Penulis

Tabel 4.19 Pengukuran Skoring Risiko pada metode pembayaran Collection Payment - Against Document

\begin{tabular}{|c|c|c|c|c|c|c|}
\hline No & Kejadian Tidak Diinginkan & Peluang & $\begin{array}{l}\text { Skala Peluang } \\
\qquad \text { I - } 5\end{array}$ & Dampak & $\begin{array}{c}\text { Skala } \\
\text { Dampakl - } 5\end{array}$ & Risiko \\
\hline $\mathrm{I}$ & Barang yang dikirimkan tidak sesuai dengan pesanan importir & JarangTerjadi & I & Besar & 4 & 4 \\
\hline 2 & Pembayaran pelunasan tidak dibayarkan oleh importir. & JarangTerjadi & I & Besar & 3 & 3 \\
\hline 3 & Jadwal pengiriman pesanan mundur. & SeringTerjadi & 3 & Besar & 5 & 15 \\
\hline 4 & $\begin{array}{l}\text { Dokumen ekspor tidak sesuai dengan ketentuan di negara } \\
\text { importir. }\end{array}$ & JarangTerjadi & 2 & Besar & 4 & 8 \\
\hline
\end{tabular}

Sumber :Hasil olahan Penulis

Heat Map 3 ; Metode pembayaran Collection Payment Against Document

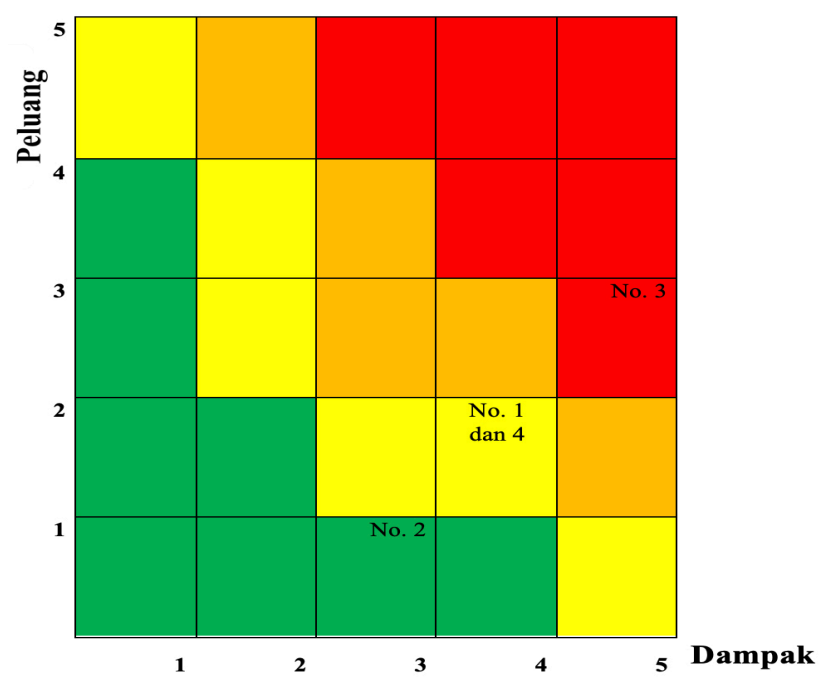

\section{I.4 Consignment / Titip Jual - Proses}

Metode pembayaran / consignment untuk saat ini hampir tidak pernah digunakan pada suatu transaksi pembayaran pada ekspor impor. Metode ini memiliki risiko yang sangat besar bagi eksportir, karena eksportir menyerahkan barangnya tanpa pembayaran apapun terlebih dahulu. Eksportir baru akan menerima pembayaran setelah barang terjual di negara importir.

Metode pembayaran consignment/ titip jual lebih banyak digunakan pada perdagangan domestik/ dalam negeri. Sebagai contoh suatu produk yang belum begitu terkenal biasanya dititip jualkan oleh produsen pada pasar modern.

Faktor yang mendorong dilakukannya pembayaran Consigmnent ini, antaralain :

I. Kepercayaan dari eksportir kepada importir yang sudah saling mengenal.

2. Eksportir dan importir merupakan mitra kerja dalam satu badan usaha.Ekspotir mempunyai likuiditas yang cukup untuk membayar dimuka.

\section{I.4.I Identifikasi Kejadian Yang Tidak Diinginkan ;}

I. Barang yang dikirimkan tidak laku terjual.

2. Impotir melakukan wanprestasi, tidak mau membayar.

3. Pengembalian/ Retur barang oleh importir. 
Tabel 4.20 Kejadian Tidak Diinginkan pada metode pembayaran Consignment / Titip Jual

\begin{tabular}{|c|c|c|c|c|c|}
\hline \multirow[t]{2}{*}{ No. } & \multirow{2}{*}{$\begin{array}{l}\text { Kejadian Tidak } \\
\text { Diinginkan }\end{array}$} & \multirow[t]{2}{*}{ Peluang Terjadi } & \multirow[t]{2}{*}{ Dampak } & \multicolumn{2}{|l|}{ Mitigasi } \\
\hline & & & & Peluang & Dampak \\
\hline I. & $\begin{array}{l}\text { Barang yang } \\
\text { dikirimkan tidak } \\
\text { laku terjual } \\
\text { karena sudah out } \\
\text { of date. }\end{array}$ & $\begin{array}{l}\text { I. Sering terjadi, } \\
\text { karena pengimport } \\
\text { tidak mempunyai } \\
\text { beban yang besar } \\
\text { untuk melakukan } \\
\text { penjualan. }\end{array}$ & $\begin{array}{l}\text { 2. Besar, karena kerugian } \\
\text { materi bagi eksportir. } \\
\text { 3. Besar, Produk } \\
\text { makanan menjadi } \\
\text { kedaluarsa. } \\
\text { 4. Besar, Produk lifestyle } \\
\text { mengalami pergantian } \\
\text { model. }\end{array}$ & $\begin{array}{ll}\text { - } & \text { Menghindari } \\
\text { transaksi. } \\
\text { Mitra kerja harus } \\
\text { sudah saling } \\
\text { mengenal atau } \\
\text { didalam satu } \\
\text { grup usaha. }\end{array}$ & $\begin{array}{l}\text { - Mengirimkan barang } \\
\text { dalam jumlah } \\
\text { terbatas. } \\
\text { - Produk yang } \\
\text { dikirimkan memiliki } \\
\text { masa daluarsa yang } \\
\text { cukup panjang. } \\
\text { - Menjual murah/ } \\
\text { memberikan diskon } \\
\text { besar untuk barang } \\
\text { - yang belum laku. }\end{array}$ \\
\hline
\end{tabular}

Sumber: Hasil olahan Penulis

Tabel 4.2I Kejadian Tidak Diinginkan pada metode pembayaran Consignment / Titip Jual

\begin{tabular}{|l|l|l|l|l|l|}
\hline No. & $\begin{array}{l}\text { Kejadian Tidak } \\
\text { Diinginkan }\end{array}$ & PeluangTerjadi & Dampak & Mitigasi & Dampak \\
\hline 2. & $\begin{array}{l}\text { Impotir melakukan } \\
\text { wanprestasi, tidak mau } \\
\text { membayar. }\end{array}$ & $\begin{array}{l}\text { I. Sering Terjadi, } \\
\text { karena importir ingin } \\
\text { melakukan kerjasama } \\
\text { jangka panjang dan } \\
\text { terikat } \\
\text { perjanjian. }\end{array}$ & $\begin{array}{l}\text { I. Besar, karena eksportir } \\
\text { mengalami kerugian } \\
\text { materil. }\end{array}$ & $\begin{array}{l}\text { I. Eksportir } \\
\text { dan eksportir } \\
\text { menandatangani } \\
\text { kontrak perjanjian. }\end{array}$ & Tidak ada \\
\hline
\end{tabular}

Sumber : Hasil olahan Penulis

Tabel 4.22 Kejadian Tidak Diinginkan pada metode pembayaran Consignment / Titip Jual

\begin{tabular}{|l|l|l|l|l|l|}
\hline No. & $\begin{array}{l}\text { Kejadian } \\
\text { Diinginkan }\end{array}$ & Tidak & PeluangTerjadi & Dampak & Peluang \\
\hline 3. & $\begin{array}{l}\text { Pengembalian/ } \\
\text { Retur } \\
\text { barang oleh } \\
\text { importir. }\end{array}$ & $\begin{array}{l}\text { I. Jarang terjadi, } \\
\text { karena biaya } \\
\text { transportasi } \\
\text { pengembalian sangat } \\
\text { besar. }\end{array}$ & $\begin{array}{l}\text { 2. Besar, eksportir } \\
\text { akan menanggung biaya } \\
\text { biaya pengirman kembali. }\end{array}$ & Tidak ada & $\begin{array}{l}\text { I. Eksportir } \\
\text { mengijinkan importir } \\
\text { untuk menjual murah, } \\
\text { "sale" discount yang } \\
\text { besar agar } \\
\text { barang habis terjual. }\end{array}$ \\
\hline
\end{tabular}

Sumber:Hasil olahan Penulis 
Tabel 4.4.I.4 Pengukuran Skoring Risiko pada metode pembayaran Consignment / Titip Jual

\begin{tabular}{|c|c|c|c|c|c|c|}
\hline No & Kejadian Tidak Diinginkan & Peluang & $\begin{array}{l}\text { Skala Peluang } \\
\text { I - } 5\end{array}$ & Dampak & $\begin{array}{l}\text { Skala } \\
\text { Dampak I - } 5\end{array}$ & Risiko \\
\hline I & Barang yang dikirimkan tidak laku terjual. & Sering Terjadi & 5 & Besar & 5 & 25 \\
\hline 2 & $\begin{array}{l}\text { Impotir melakukan wanprestasi, tidak mau } \\
\text { membayar. }\end{array}$ & Sering Terjadi & 5 & Besar & 5 & 25 \\
\hline 3 & Pengembalian/ Retur barang oleh importir. & Sering Terjadi & 2 & Besar & 4 & 8 \\
\hline
\end{tabular}

Sumber:Hasil olahan Penulis

Heat Map 4 ; Metode pembayaran Consignment / Titip Jual

\section{I.5. Letter Of Credit (L/C) - Proses}

Letter Credit atau biasa disingkat L/C, adalah satu jenis syarat pembayaran yang sering digunakan dan saat ini dinilai cara pembayaran yang paling aman dalam perdagangan internasional.Metode pembayaran menggunakan L/C dapat dikatakan Mitigasi dari semua metode pembayaran yang ada, walaupun masih tetap memiliki risiko. L/C merupakan perjanjian pembayaran yang diterbitkan oleh suatu bank (issuing/ opening bank) yang merupakan Bank Devisa yang bertindak atas permintaan nasabahnya importir/ applicant/ untuk melakukan pembayaran atas dokumen ekspor-impor yang dikirimkan oleh penerima L/C (eksportir/ beneficiary). Mekanisme kerja pembayaran yang menggunakan L/C akan melibatkan sebuah bank, bank sebagai penerbit L/C akan memberikan jaminan bahwa importir akan melakukan pembayaran sesuai dengan persyaratan dan kesepakatan yang disetujui antara eksporti dan importir yang tertulis pada klausul Letter of Credit. Sebelum menerbitkan L/C untuk importir, pihak bank penerbit akan melakukan analisis risiko, yang mirip dengan analisis saat menyalurkan kredit. Kredibilitas bank dipertaruhkan, sehingga tidak semua bank dapat menerbitkan L/C yang bisa dipercaya. Nilai yang wajib dibayarkan oleh penerbit Letter of Credit harus disetorkan oleh pihak importir kepada bank. Bagi nasabah bank yang sudah lama menjalin hubungan dengan pihak Bank, kredibilitas dan kondite usaha sudah dinilai baik oleh pihak Bank, umumnya bisa mendapatkan fasilitas pembiayaan terhadap penerbitan L/C dari pihak Bank sesuai dengan syarat dan ketentuan yang diterapkan oleh pihak bank. Pihak eksportir umumnya akan mempersyaratkan pihak importir dengan memberikan beberapa nama bank yang dianggap kredibel untuk menerbitkan L/C berdasarkan rekomendasi dari bank penerima (mewakili eksportir). Issuing Bank (penerbit L/C) sudah mempunyai hubungan kerja koreponden dengan Advising Bank sebagai lembaga keuangan yang di tunjuk oleh Beneficiary/ eksportir (bank penerima), sebagai jaminan bahwa bank tersebut tidak akan bermasalah pada saat $\mathrm{L}$ C jatuh tempo pembayaran Ini untuk lebih meyakinkan agar tidak terjadi gagal bayar. Umumnya pihak eksportir lebih menginginkan L/C diterbitkan oleh bank yang sudah besar, bank pemerintah, dan mempunyai kredibiltas yang tinggi. Biaya penerbitan L/C lebih mahal dibandingkan dengan metode pembayaran transfer. Metode ini sangat aman bagi eksportir, dan juga eksportir bisa mendapatkan fasiltitas pembiayaan dari pihak bank penerima dengan meng-agunkan L/C. Bagi Importir metode ini mengandung resiko, apabila pesanan gagal dikirimkan oleh produsen, maka biaya proses dan penerbitan L/C sangat mahal, yang akan dibebankan menjadi tanggungan Eksportir.

Ada beberapa jenis L/C yang bisa digunakan, sangat tergantung darinegosiasasi antara Eksportir dan Importir. Sebagai benefeciary, umumnya Eksportir lebih menginginkan menerima $\mathrm{L} / \mathrm{C}$ sight.

LC sight adalah L/C yang jatuh temponya atas unjuk (sight). Maksudnya, pembayaran akan diterima beneficiary setelah dokumen ekspor atas barang barang dan pengapalan yang dikirimkannya diterima oleh Issuing Bank (bank penerbit LC), dengan catatan seluruh dokumen sudah sesuai dengan syarat dan kondisi yang ditentukan dalam L/C.

Dikutip dari https://id.wikipedia.org/wiki/Surat_kredit, adapun proses pembayaran melalui L/C dapat dijelaskan sebagai berikut ;

I. Importir meminta kepada banknya (bank devisa) untuk membuka suatu $L / C$ untuk dan atas nama eksportir. Dalam hal ini, importir bertindak sebagai opener. Bila importir sudah memenuhi ketentuan yang berlaku untuk impor seperti keharusan adanya surat izin impor, maka bank melakukan kontrak valuta (KV) dengan importir dan melaksanakan pembukaan L/C atas nama importir. Bank dalam hal ini bertindak sebagai opening/issuing bank.

2. Pembukaan L/C ini dilakukan melalui salah satu koresponden bank di luar negeri. Koresponden bank yang bertindak sebagai perantara kedua ini disebut sebagai advising bank atau notifiying bank. Advising bank memberitahukan kepada eksportir mengenai pembukaan L/C tersebut. Eksportir yang menerima 
L/C disebut beneficiary.

3. Eksportir menyerahkan barang ke Carrier, sebagai gantinya Eksportir akan mendapatkan bill of lading.

4. Eksportir menyerahkan seluruh dokumen ekspor yang dipersyaratkan pada Advising bank untuk diserahkan kepada Issuing Bank/ Paying Bank guna mendapatkan pembayaran.

5. Issuing Bank/ Paying bank kemudian meneruskan dokumen ekspor (copy) kepada Importir untuk kembali diteliti, dengan memberikan jangka waktu tertentu sebelum Issuing bank/ Paying bank melakukan pembayaran kepada Beneficiary melalui Advising Bank.

6. Setelah melakukan pembayaran, Issuing Bank menyerahkan dokumen ekspor (original) kepada Importir.

7. Importir menyerahkan ekspor dokumen/ bill of lading kepada Carrier untuk ditukarkan dengan barang yang dikirimkan oleh eksportir.

8.

\subsection{I.I Identifikasi Kejadian Yang Tidak Diinginkan ;}

Pada proses penerbitan L/C, harus diperhatikan secara teliti beberapa hal yangbisa menjadi risiko yaitu ;

I. Issuing Bank diragukan kredibilitasnya.

2. Importir mengajukan penangguhan pencairan $L / C$..
3. Klausul perjanjian yang tertera pada L/C harus dibaca dengan jelas.

4. Fraud L/C, Barang tidak dikirimkan, tetapi ada dokumen pengiriman.

\section{Letter Of Credit (L/C) Payment Method Process}

\section{LETTER OF CREDIT: PROCEDURE}

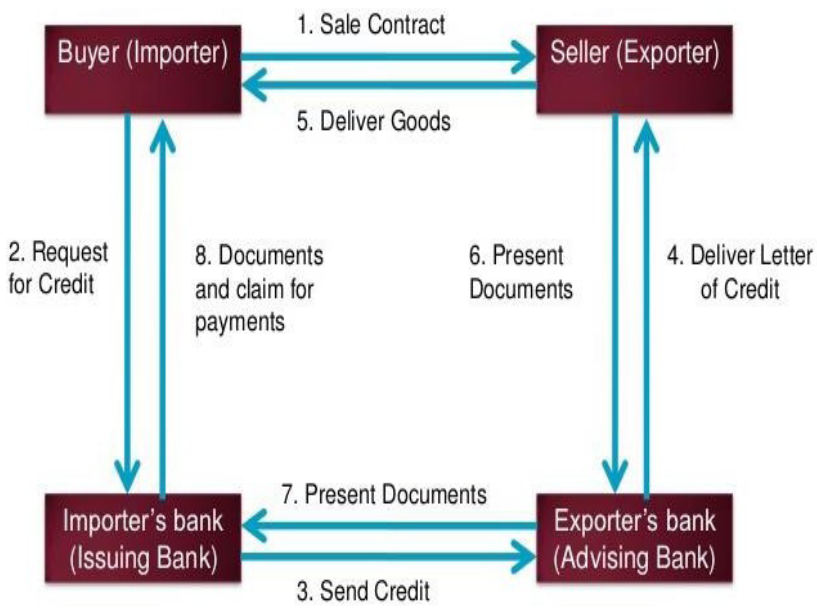

Gambar 3 : Letter Of Credit (L/C) Payment Method

Tabel 4.24 Kejadian Tidak Diinginkan pada metode pembayaran Letter Of Credit (L/C)

\begin{tabular}{|l|l|l|l|l|}
\hline No. & $\begin{array}{l}\text { Kejadian Tidak } \\
\text { Diinginkan }\end{array}$ & PeluangTerjadi & Dampak & \multicolumn{2}{l|}{ Mitigasi } \\
\hline & & & Peluang & Dampak \\
\hline I. & $\begin{array}{l}\text { Issuing Bank } \\
\text { merupakan Bank } \\
\text { Devisa yang kecil } \\
\text { dan diragukan } \\
\text { kredibiltasnya. }\end{array}$ & $\begin{array}{l}\text { I. Jarang terjadi, karena } \\
\text { Importir mengaplikasi } \\
\text { L/C bukan pada Bank } \\
\text { Devisa yang besar dan } \\
\text { terpercaya. }\end{array}$ & $\begin{array}{l}\text { I. Besar, Bisa terjadigagal } \\
\text { bayar saat dokumen } \\
\text { ekspor sudah diserahkan } \\
\text { oleh Beneficiary. }\end{array}$ & $\begin{array}{l}\text { Eksportir mensyaratkan, agar Issuing } \\
\text { Bank menggunakan Bank Devisa } \\
\text { yang besar, mempunyai kredibitas } \\
\text { yang baik,dan mempunyai kerjasama } \\
\text { dengan Advising Bank sebagai } \\
\text { Correspondence } \\
\text { Bank. }\end{array}$ \\
\hline
\end{tabular}

Sumber: Hasil olahan penulis

Tabel 4.25 Kejadian Tidak Diinginkan pada metode pembayaran Letter Of Credit (L/C)

\begin{tabular}{|l|l|l|l|l|l|}
\hline No. & Kejadian TidakDiinginkan & \multicolumn{1}{|c|}{ PeluangTerjadi } & Dampak & \multicolumn{2}{|c|}{ Mitigasi } \\
\hline & & & & \multicolumn{1}{|c|}{ Peluang } & \multicolumn{1}{c|}{ Dampak } \\
\hline 2. & $\begin{array}{l}\text { penangguhan pencairan } \\
\text { L/C.. }\end{array}$ & $\begin{array}{l}\text { Importir tidak mempunyai } \\
\text { dana yangcukup. }\end{array}$ & $\begin{array}{l}\text { 1. Besar, eksportir } \\
\text { terlambat penerima } \\
\text { pembayaran, akan } \\
\text { terjadi kesulitan aliran } \\
\text { dana kas. }\end{array}$ & $\begin{array}{l}\text { 1. Negosisasikan } \\
\text { dengan issuing bank } \\
\text { dan benefeciary bank. }\end{array}$ & $\begin{array}{l}\text { 1. Melakukan transfer } \\
\text { ke risiko kepada } \\
\text { lembaga asuransi } \\
\text { dibidang pembayaran } \\
\text { L/C. }\end{array}$ \\
\hline
\end{tabular}

Sumber : Hasil olahan Penulis 
Tabel 4.26 Kejadian Tidak Diinginkan pada metode pembayaran Letter Of Credit (L/C)

\begin{tabular}{|l|l|l|l|l|l|}
\hline No. & $\begin{array}{l}\text { Kejadian Tidak } \\
\text { Diinginkan }\end{array}$ & \multicolumn{1}{|c|}{ PeluangTerjadi } & Dampak & \multicolumn{2}{|c|}{ Mitigasi } \\
\hline 3. & $\begin{array}{l}\text { Klausul } \\
\text { perjanjian pada L/C } \\
\text { tidak sesuai dengan } \\
\text { Sales Contract. }\end{array}$ & $\begin{array}{l}\text { 1. Jarang terjadi, karena } \\
\text { Eksportir tidak membaca } \\
\text { secara detil materi yang } \\
\text { ada pada klausul perjan- } \\
\text { jian L/C.. }\end{array}$ & $\begin{array}{l}\text { 1. Besar, terjadi dispute } \\
\text { ketika akan menagih } \\
\text { pembayaran, bisa terjadi } \\
\text { gagal bayar. }\end{array}$ & $\begin{array}{l}\text { 1. Serahkan materi/ klausul } \\
\text { perjanjian kepada bidang } \\
\text { hukum/ legal yang ada di } \\
\text { kantor sendiri atau kepada } \\
\text { firma hukum, untuk dipelajari., } \\
\text { atau }\end{array}$ & $\begin{array}{l}\text { 1. Eksportir Melakukan } \\
\text { negosiasi untuk } \\
\text { 2. Eksportir melakukan } \\
\text { tindakan hukum dengan } \\
\text { melaporkan ke pihak } \\
\text { yang berwajib/ lembaga }\end{array}$ \\
\end{tabular}

Sumber:Hasil olahan Penulis

Tabel 4.27 Kejadian Tidak Diinginkan pada metode pembayaran Letter Of Credit (L/C)

\begin{tabular}{|l|l|l|l|l|l|}
\hline No. & $\begin{array}{l}\text { Kejadian Tidak } \\
\text { Diinginkan }\end{array}$ & Peluang Terjadi & Dampak & Mitigasi & Dampak \\
\hline 4. & $\begin{array}{l}\text { L/C, Barang tidak } \\
\text { dikirimkan, tetapi ada } \\
\text { dokumen pengiriman. }\end{array}$ & $\begin{array}{l}\text { 1. Jarang terjadi, pihak perbankan } \\
\text { "knowyour management" menjaga } \\
\text { kerahasiaan sistem perbankan. }\end{array}$ & $\begin{array}{l}\text { 1. Besar, } \\
\text { kerugian } \\
\text { materi bagi } \\
\text { importir. }\end{array}$ & $\begin{array}{l}\text { 1. Pihak Bank memeriksa dokumen } \\
\text { ekspor dengan teliti. } \\
\text { Pihak Bank secara terus menerus } \\
\text { menyempurnakan sistem } \\
\text { perbankan dan membina mental } \\
\text { pimpinan dan staf/ karyawan bank. }\end{array}$ & 1. Tidak Ada \\
\hline
\end{tabular}

Sumber:Hasil olahan Penulis

Tabel 4.28 Pengukuran Skoring Risiko pada metode pembayaranLetter Of Credit (L/C)

\begin{tabular}{|c|c|c|c|c|c|c|}
\hline No & Kejadian TidakDiinginkan & Peluang & Skala Peluang1 - 5 & Dampak & $\begin{array}{l}\text { Skala Dampak } \\
1 \text { - } 5\end{array}$ & Risiko \\
\hline 1 & $\begin{array}{l}\text { Issuing Bank merupakan Bank Devisa yang kecildan diragu- } \\
\text { kan kredibiltasnya. }\end{array}$ & JarangTerjadi & 1 & Besar & 5 & 5 \\
\hline 2 & Importir mengajukan penangguhan pencairan L/C.. & SeringTerjadi & 4 & Besar & 4 & 16 \\
\hline 3 & $\begin{array}{l}\text { Klausul perjanjianyang tertera pada } \mathrm{L} / \mathrm{C} \text { harus dibaca dengan } \\
\text { jelas. }\end{array}$ & JarangTerjadi & 2 & Besar & 4 & 8 \\
\hline 4 & $\begin{array}{l}\text { Fraud L/C, Barang tidak dikirimkan, tetapi ada dokumen } \\
\text { pengiriman. }\end{array}$ & JarangTerjadi & 2 & Besar & 5 & 10 \\
\hline
\end{tabular}

Sumber:Hasil olahan penulis 


\section{Penutup}

Proses perdagangan internasional (International Trade), terjadi persaingan yang sangat ketat ditingkat global dan memiliki risiko dan dampak risiko yang tinggi. Selain kualitas produk, waktu distribusi, program pemasaran, metode pembayaran merupakan salah satu bagian dari persaingan di tingkat Global. Keamanan dan kenyamanan suatu metode pembayaran sangat diharapkan oleh para pelaku ekspor impor. Selama ini yang biasa digunakan adalah metode pembayaran melalui penerbitan Letter of Credit (L/C), tetapi lambat laun metode tersebut menjadi tidak populer dikalangan perusahaan ekspor impor berskala kecil menengah. Prosedur penerbitan dirasakan sangat menyulitkan para pengusaha. Kondite bank penerbit menjadi taruhannya apakah L/C tersebut bisa efektif pada saatnya?. Perananan pemerintah juga diharapkan penuh dalam membantu terjadinya transaksi yang aman. Pemerintah perlu lebih memperluas dan memperbanyak perjanjian kerjasama antar negara dalam hal keuangan dan pembiayaan dengan pihak perbankan internasional. Gagal bayar menjadi momok bagi perusahaan yang berskala kecil dan menengah, untuk itu perlu peran pemerintah untuk melakukan perlindungan dan pemberian fasilitas.

Metode Collection dengan pola Payment Against Document dapat dikatakan memberikan keamanan dan kenyamanan yang setara kepada para pelaku ekspor impor. Dimana pengekspor bisa mendapatkan uang muka untuk memproduksi produk yang dibeli oleh importir, dan disisi lain importir menunjukan keseriusan untuk membeli produk dengan mau memberikan uang muka yang disepakati. Metode ini mengatur eksportir harus terlebih dahulu menginformasikan kepada importir, bahwa barang sudah terkirim dengan mengirimkan copy; Bill of Leading yang menyatakan barang telah dimuat di kapal dan sudah berangkat. Importir segera mempersiapkan dana untuk pembayaran.

Proses penyediaan produk yang akan dikirim dilakukan setelah Produsen (Eksportir) menerima pembayaran. Umumnya persiapan dilakukan antara 3 minggu sampai 6 minggu, juga sangat tergantung jenis produk yang dibeli.

Setelah produk pesanan sudah siap untuk dikirimkan, maka pihak Produsen (Eksportir) akan memberitahukan pihak Pembeli (Importir) bahwa produk sudah siap diberangkatkan. Tujuan pemberitahuan ini adalah agar Pembeli (Importir) sudah mulai mempersiapkan pembayaran pelunasan.

Metode ini lebih menitik beratkan untuk memperkecil Risiko di kedua belah pihak, tetapi Risiko terbesar ada pada pihak Produsen (Eksportir). Risiko yang bisa terjadi adalah ketika pihak Pembeli (Importir) tidak bisa mengirimkan pembayaran pelunasan sebesar $70 \%$ sampai dengan $80 \%$.

Metode payment against document juga bisa saja tidak menyertakan perbankan, tetapi apabila menyertakan perbankan, biaya yang dibebankan banktidak terlalu besar, karena importir dapat menggunakan pembayaran dengan cara TT (Telegrapic Transfer). Walapun begitu, pihak importir harus berhati- hati dan telah mengenal dengan baik pihak eksportir.

\section{DAFTAR PUSTAKA}

Indah Puji Astuti Utami, Djuwityastuti dan Anugrah Adiastuti, (2016)

Letter Of Credit (L/C) Sebagai Cara Pembayaran Transaksi Perdagangan Internasional Dalam Kerangka Asean EconomicCommunity Privat Law Vol. IV No.I

Lam, James, (2017), Enterprise Risk Management, PT. Ray, Jakarta

Karbela (2009) Penyalahgunaan L/ C, Studi Kasus L/C Fiktif BNI,) Jurrnal Hukum dan Pembangunan Tahun ke-39 No.I

Kardoyo, M.Pd. dan Ahmad Nurkhin, S.Pd. M.Si. Dr, (20I6), Perdagangan International, Kementerian Pendidikan dan Kebudayaan.

Manurung, Adler Haymans (2018), Pengukuran Risiko (Revisi), PT. Adler Manurung Press,

Manurung, Adler Haymans (2019), Risk Operasional, Gramedia, Jakarta

Mediator Investor, (20I3), Jenis-jenis L/C (Letter of Credit) dari mediatorinvestor.wordpress.com/artikel/jenis-jenis-lc/

Muhammad Harlianto Purnama, Topowijono, Achmad Husaini (20l4) Analisis Penerapan Manajemen Risiko Pada Perusahaan Eksportir Yang Menggunakan Metode Pembayaran Letter Of Credit Jurnal Administrasi Bisnis (JAB) Vol. 16 No. I
Prawitra Thalib, SH.,MH, (20II), Mekanisme Lalu Lintas Pembayaran Luar Negeri Dalam Kegiatan Ekspor Impor Yuridika:Volume 26 No 3

Rachbini, J. Didik., Ono, Swidi. (2000) Bank Indonesia: Menuju Independensi Bank Sentral. PT. Mardi Mulyo. Jakarta.

T. Sunaryo. (2007). Manajemen Risiko Finansial. Salemba Empat. Jakarta.

T. Sunaryo. (2015). Risiko Operasional Salemba Empat. Jakarta.

\section{Paraturan Perundang Undangan}

Direktorat Jenderal Pengembangan Ekspor Nasional (DJPEN), Kementerian Perdagangan Republik Indonesia (20I I) Metode Pembayaran dari http:// djpen.kemendag.go.id/app_frontend/contents/97-metode- pembayaran

Peraturan Pemerintah Repubuk Indonesia Nomor 29 Tahun 2017 Tentang Cara Pembayaran Barang Cara Penyerahan Barang Dalam Kegiatan Ekspor Dan Impor.

Undang-Undang Republik Indonesia Nomor 20 Tahun 2008 Tentang Usaha Mikro, Kecil Menengah.

Undang-Undang Republik Indonesia Nomor 4 Tahun 2014 Tentang Perindustrian.

Undang-Undang Republik Indonesia Nomor 7 Tahun 2014 Tentang Perdagangan. 